Article

\title{
Understory Limits Surface Runoff and Soil Loss in Teak Tree Plantations of Northern Lao PDR
}

\author{
Layheang Song ${ }^{1,2}$, Laurie Boithias ${ }^{1, * \mathbb{D}}$, Oloth Sengtaheuanghoung ${ }^{3}$, Chantha Oeurng ${ }^{2}$, \\ Christian Valentin ${ }^{4}$, Bounthan Souksavath ${ }^{5}$, Phabvilay Sounyafong ${ }^{6}$, Anneke de Rouw ${ }^{4}$, \\ Bounsamay Soulileuth ${ }^{6}$, Norbert Silvera ${ }^{4}$, Bounchanh Lattanavongkot ${ }^{5}$, Alain Pierret ${ }^{6}$ and \\ Olivier Ribolzi ${ }^{1}$
}

1 GET, Université de Toulouse, CNRS, IRD, UPS, 31400 Toulouse, France; layheangsong@itc.edu.kh (L.S.); olivier.ribolzi@ird.fr (O.R.)

2 Research and Innovation Center (RIC), Faculty of Hydrology and Water Resources Engineering, Institute of Technology of Cambodia, Phnom Penh 12156, Cambodia; chantha@itc.edu.kh

3 Department of Agricultural Land Management (DALaM), Ministry of Agriculture and Forestry, Vientiane 01000, Laos; oloth_s@hotmail.com

4 Institute of Ecology and Environmental Sciences of Paris (iEES-Paris), Sorbonne Université, Univ Paris Est Creteil, IRD, CNRS, INRA, 75005 Paris, France; christian.valentin@ird.fr (C.V.); anneke.de_rouw@ird.fr (A.d.R.); norbert.silvera@ird.fr (N.S.)

5 Luang Prabang Teak Program (LPTP-TFT), Luang Prabang Provincial Forestry Section, Luang Prabang 06000, Laos; b.souksavath@earthworm.org (B.S.); chanh.lptp@gmail.com (B.L.)

6 IRD, IEES-Paris UMR 242, c/o National Agriculture and Forestry Research Institute, Vientiane 01000, Laos; phabvilay_laopdr@yahoo.com (P.S.); sbounsamay@gmail.com (B.S.); alain.pierret@ird.fr (A.P.)

* Correspondence: laurie.boithias@get.omp.eu; Tel.: +33-561-332-712

Received: 14 July 2020; Accepted: 15 August 2020; Published: 19 August 2020

\begin{abstract}
Many mountainous regions of the humid tropics experience serious soil erosion following rapid changes in land use. In northern Lao People's Democratic Republic (PDR), the replacement of traditional crops by tree plantations, such as teak trees, has led to a dramatic increase in floods and soil loss and to the degradation of basic soil ecosystem services such as water filtration by soil, fertility maintenance, etc. In this study, we hypothesized that conserving understory under teak trees would protect soil, limit surface runoff, and help reduce soil erosion. Using $1 \mathrm{~m}^{2}$ microplots installed in four teak tree plantations in northern Lao PDR over the rainy season of 2017, this study aimed to: (1) assess the effects on surface runoff and soil loss of four understory management practices, namely teak with no understory (TNU; control treatment), teak with low density of understory (TLU), teak with high density of understory (THU), and teak with broom grass, Thysanolaena latifolia (TBG); (2) suggest soil erosion mitigation management practices; and (3) identify a field visual indicator allowing a rapid appraisal of soil erosion intensity. We monitored surface runoff and soil loss, and measured teak tree and understory characteristics (height and percentage of cover) and soil surface features. We estimated the relationships among these variables through statistics and regression analyses. THU and TBG had the smallest runoff coefficient ( $23 \%$ for both) and soil loss (465 and $381 \mathrm{~g} \cdot \mathrm{m}^{-2}$, respectively). The runoff coefficient and soil loss in TLU were $35 \%$ and $1115 \mathrm{~g} \cdot \mathrm{m}^{-2}$, respectively. TNU had the highest runoff coefficient and soil loss $\left(60 \%, 5455 \mathrm{~g} \cdot \mathrm{m}^{-2}\right)$ associated to the highest crusting rate (82\%). Hence, the soil loss in TBG was 14-times less than in TNU and teak tree plantation owners could divide soil loss by 14 by keeping understory, such as broom grass, within teak tree plantations. Indeed, a high runoff coefficient and soil loss in TNU was explained by the kinetic energy of rain drops falling from the broad leaves of the tall teak trees down to bare soil, devoid of plant residues, thus leading to severe soil surface crusting and soil detachment. The areal percentage of pedestal features was a reliable indicator of soil erosion intensity. Overall, promoting understory, such as broom grass, in teak tree plantations would: (1) limit surface runoff and improve
\end{abstract}


soil infiltrability, thus increase soil water stock available for both root absorption and groundwater recharge; and (2) mitigate soil loss while favoring soil fertility conservation.

Keywords: overland flow; inter-rill erosion; teak tree plantation; understory; broom grass; South-East Asia; land management; soil erosion

\section{Introduction}

Mountain areas of the humid tropics are characterized by steep slopes and heavy rains [1]. Hence these regions are prone to high surface runoff and soil erosion [2]. Conversion of natural forest to e.g., agricultural land exacerbates runoff production and soil erosion, leading to physicochemical and biological changes of the altered ecosystems $[3,4]$.

On-site effects of increased soil erosion include the reduction of soil quality impacting the sustainability of agricultural production [5], and economics, due to the loss of ecosystem services [6]. The tremendously higher rate of soil loss compared to its formation rate threatens food production and environmental quality (water, soil, and air) [7-9].

Off-site effects comprise floods, depletion of groundwater recharge, degradation of stream environments, and downstream sedimentation $[5,10]$. In addition, the adsorption of organic and inorganic matter on soil particles and suspended sediments plays a leading role in the transport of nutrients [11], radionuclides [12], metals [13], pesticides [14], and bacterial pathogens [15,16]. Higher contamination of rivers by fecal bacteria is often correlated to higher in-stream suspended sediment concentration $[17,18]$. Sediment loads cause massive accumulation of fine sediments to river beds and cause the siltation of irrigation canals and dam reservoirs [19-21], thus reducing their life spans. All of these off-site effects lead to high economic and ecological costs (i.e., sedimentation, flooding, landslides, water eutrophication, biodiversity loss, land abandonment, destruction of infrastructures) [6].

Natural forests are known for their protective effect against erosion [22]. Forests have favorable hydrodynamic properties for surface infiltration [23], subsurface drainage [24] due to the biological activity, and the development of macropores in the litter and underneath. A fraction of rainfall, known as throughfall, is intercepted by the canopy and the underlying vegetative strata [25]. The amount of water and the kinetic energy of drops corresponding to throughfall is lower than that of rainfall, thus reducing soil erosion. Kinetic energy is the main factor initiating soil erosion; raindrops hit the soil surface and disaggregate the soil structure [26] resulting in redistribution of soil material by splash effect [5]. Kinetic energy is controlled by rainfall (amount, drop size, fall velocity), vegetation characteristics (height, cover, residues) [27], and slope [26].

In the mountainous region of northern Lao People's Democratic Republic (PDR), widespread agricultural practices are known to increase surface runoff, soil erosion, and in-stream suspended sediment concentrations compared to natural forest $[3,23]$. In particular, commercial perennial monocultures, such as teak tree plantations, lead to a drastic surface runoff increase [28] and exacerbate soil loss along hillslopes [29,30]. In teak tree plantations, such as the old teak trees (high timbers with broad leaves) growing in the Houay Pano catchment, surface runoff and soil erosion are likely related to recurrent understory and leaf litter suppression by burning at the end of the dry season, leaving the soil bare and exposed to the kinetic energy of the raindrops [31].

Land use, understory cover, and soil surface condition, are the main drivers influencing the infiltration of water into the soil [32,33]. Living plant roots modify both mechanical and hydrological characteristics of the soil matrix and negatively influence the soil erodibility $[34,35]$. Understory and plant residues on soil surface are known to efficiently attenuate the effect of splash and thus soil detachment [36-40]. Soil surface features have a strong impact on surface runoff and soil erosion: soil aggregation limits surface runoff generation and soil loss [41,42], while crusted soils can be 
self-protecting from erosion because of their high surface shear stress resistance, but they also promote surface runoff, hence downstream erosion, especially on non-crusted areas [26,30]. For example, in northern Lao PDR, splash in teak tree plantations increases soil erosion, and the absence of understory enhances the effect of splash [29]. By adapting the model developed by [43], Patin et al. [31] showed that plant residues and weed cover at soil surface were the main attenuation factors of soil erosion. In northern Thailand, soil erosion in rubber tree plantations decreased when understory was grown [44]. Indeed, in northern Lao PDR headwater catchments, the runoff coefficient is approximately $55 \%$ under teak trees at the plot scale [30], whereas it nearly doubled from $16 \%$ to $31 \%$ within 13 years at the catchment scale [29], resulting from the absence of understory in the teak tree plantation area. In particular, mature teak trees with limited understory were shown to export respectively 5.5- and 31-times more water and soil than broom grass (Thysanolaena latifolia) at the plot scale [30].

Hence, in this paper, we hypothesized that conserving understory such as broom grass, which provides income to farmers through broom making and selling [45], protects soil, limits surface runoff, and helps to reduce soil erosion in teak tree plantations. The overarching goal of this study, conducted in the teak tree plantations of Ban Kokngew, northern Lao PDR, was thus to find the best strategy to contribute to sustainable agricultural production. In this context, the three objectives of our $1 \mathrm{~m}^{2}$ microplot experiment performed during the June to October monsoon period of 2017 were to: (1) assess the effects on surface runoff and soil loss of four understory management practices, namely teak with no understory (TNU; control treatment), teak with low density of understory (TLU), teak with high density of understory (THU), and teak with broom grass (TBG); (2) suggest soil erosion mitigation management practices; and (3) identify a field visual indicator allowing a rapid appraisal of soil erosion intensity.

\section{Materials and Methods}

\subsection{Study Area and Experimental Plots}

We conducted the experiment in 2017 in teak tree plantations surrounding Ban Kokngew, a village located in Luang Prabang Province, northern Lao PDR, and predominantly situated over Acrisol soil and Carboniferous and Permian limestones (Figure 1). The climate is sub-tropical humid and is characterized by a monsoon regime with a dry season from November to May, and a rainy from June to October. Mean annual rainfall recorded at Luang Prabang from 1960 to 2006 was 1268 mm, about 76\% of which falls during the rainy season. The mean annual temperature is $25.3^{\circ} \mathrm{C}$. Mean annual reference evapotranspiration is $1116 \mathrm{~mm}$. The study area belongs to the mountainous region of northern Laos PDR. More specifically, the area is located within the "Luang Prabang mountain rain forest" ecoregion [46]. The area has been experiencing dramatic land use changes in the last decade with the introduction of the teak tree plantations [29,47].

We selected this area because it presents, over short distances, diversely managed teak tree plantations. This area used to be shifting cultivation land. This last decade, teak has gradually replaced most of the fields and spontaneous forest regrowth because of land degradation, lack of labor and the expectation of profitability. Teak timber is valued for its durability and water resistance; it is used for furniture and construction in the rapidly developing city of Luang Prabang. Farmers spontaneously adopted different management practices within their plantations, and we selected four sites corresponding to actual contrasted situations that we intended to test and compare.

Aside from the most common situation which is teak with no understory (TNU), i.e., teak tree plantations where soil is kept bare, often by burning the leaf litter and understory, and which represented our control situation, we considered the three following alternative treatments: teak trees grown with high density understory (THU), teak trees grown with low density and/or periodically pruned understory (TLU), and teak trees grown with broom grass, Thysanolaena latifolia (TBG). In each treatment, we set up $1 \mathrm{~m}^{2}$ microplots (Figure 2) with six replicates per treatment. 


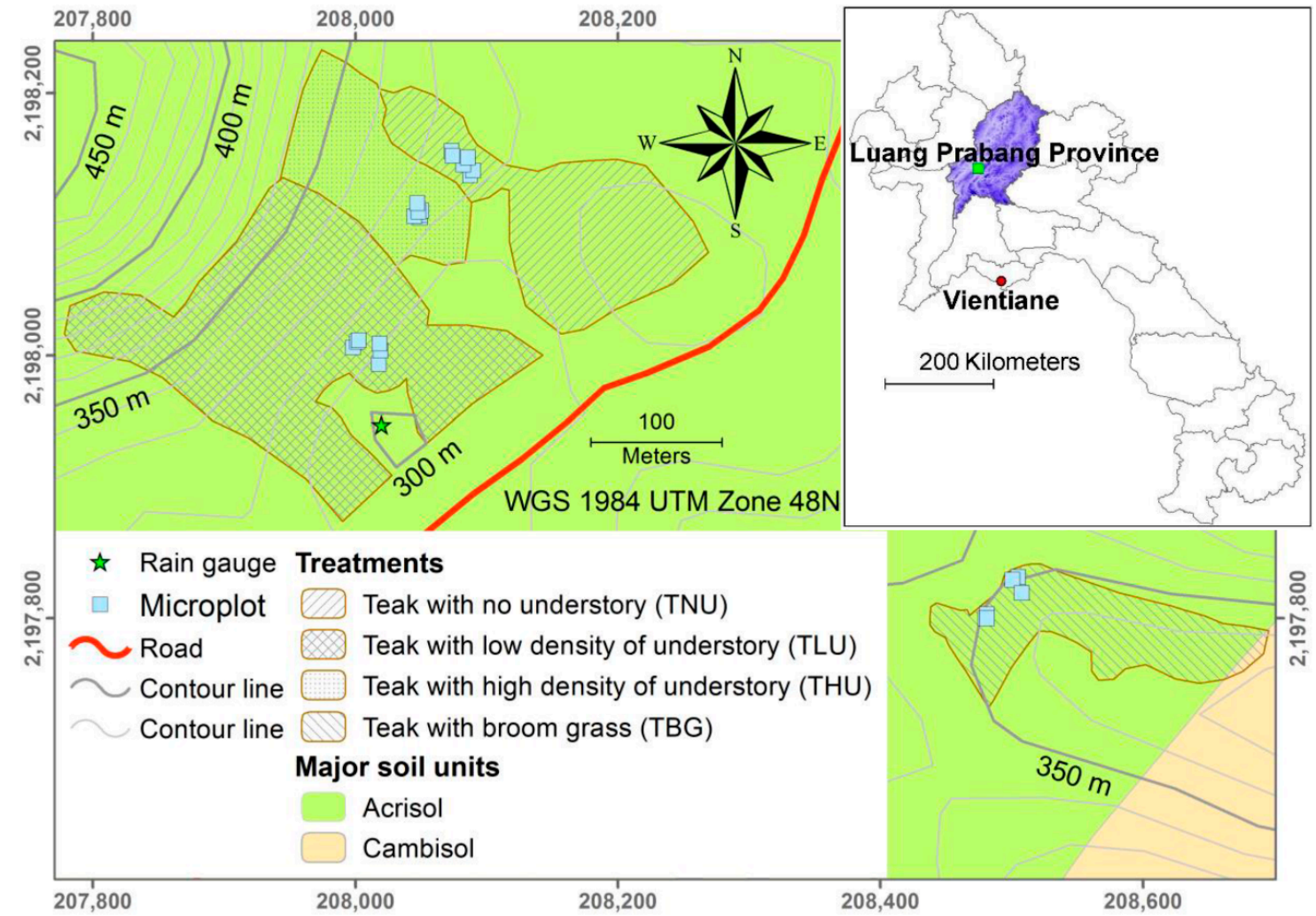

Figure 1. Study site in Ban Kokngew, Luang Prabang Province, Lao People's Democratic Republic, with location of experimental microplots, treatments, and soil types.

The age of the teak trees in the four treatments varied between 12 years in TBG and 18 years in TLU (Table 1). Elevation above sea level ranged between $316 \mathrm{~m}$ in TLU and $358 \mathrm{~m}$ in TBG, whereas TNU and THU were both at $325 \mathrm{~m}$. The slopes of the microplots ranged between $39 \%$ in TNU and $46 \%$ in TBG. The slope difference between TNU and TBG was not considered a limitation for the comparison of treatments in this study since the effect of slope is known to be imperceptible for these slope ranges [31]. The size of the teak tree plantations was $1.87 \mathrm{ha}, 3.78 \mathrm{ha}, 1.21 \mathrm{ha}$, and $1.32 \mathrm{ha}$ in TNU, TLU, THU, and TBG, respectively. We installed a rain gauge near the treatments TNU, TLU, and THU, and approximately $500 \mathrm{~m}$ from TBG (Figure 1).

Table 1. Characteristics of the four experimental sites in 2017, measured on 14 December 2017, in Ban Kokngew, Luang Prabang Province, Lao People's Democratic Republic. TNU: teak with no understory; TLU: teak with low density of understory; THU: teak with high density of understory; TBG: teak with broom grass.

\begin{tabular}{|c|c|c|c|c|c|c|c|c|c|}
\hline Treatment & $\begin{array}{l}\text { Teak Height } \\
\text { (m) }\end{array}$ & $\begin{array}{c}\text { Teak Stem } \\
\text { Diameter } \\
(\mathrm{cm})\end{array}$ & $\begin{array}{c}\text { Teak Cover } \\
(\%)\end{array}$ & $\begin{array}{c}\text { Tree } \\
\text { Density } \\
\left(\text { tree }^{\prime} \mathbf{h a}^{-1}\right)\end{array}$ & $\begin{array}{l}\text { Teak Age } \\
\text { (Years) }\end{array}$ & $\begin{array}{l}\text { Altitude } \\
\text { (m) }\end{array}$ & $\begin{array}{l}\text { Slope } \\
(\%)\end{array}$ & $\begin{array}{l}\text { Latitude } \\
\quad\left({ }^{\circ}\right)\end{array}$ & $\begin{array}{c}\text { Longitude } \\
\left({ }^{\circ}\right)\end{array}$ \\
\hline TNU & 22 & 15.3 & 35 & 1200 & 15 & 325 & 39.2 & 19.8577 & 102.21269 \\
\hline TLU & 22 & 17.0 & 30 & 1000 & 18 & 316 & 40.7 & 19.85641 & 102.21202 \\
\hline THU & 20 & 15.4 & 70 & 800 & 15 & 325 & 41.5 & 19.85735 & 102.21237 \\
\hline TBG & 20 & 16.4 & 60 & 1000 & 12 & 358 & 45.5 & 19.85475 & 102.21666 \\
\hline
\end{tabular}



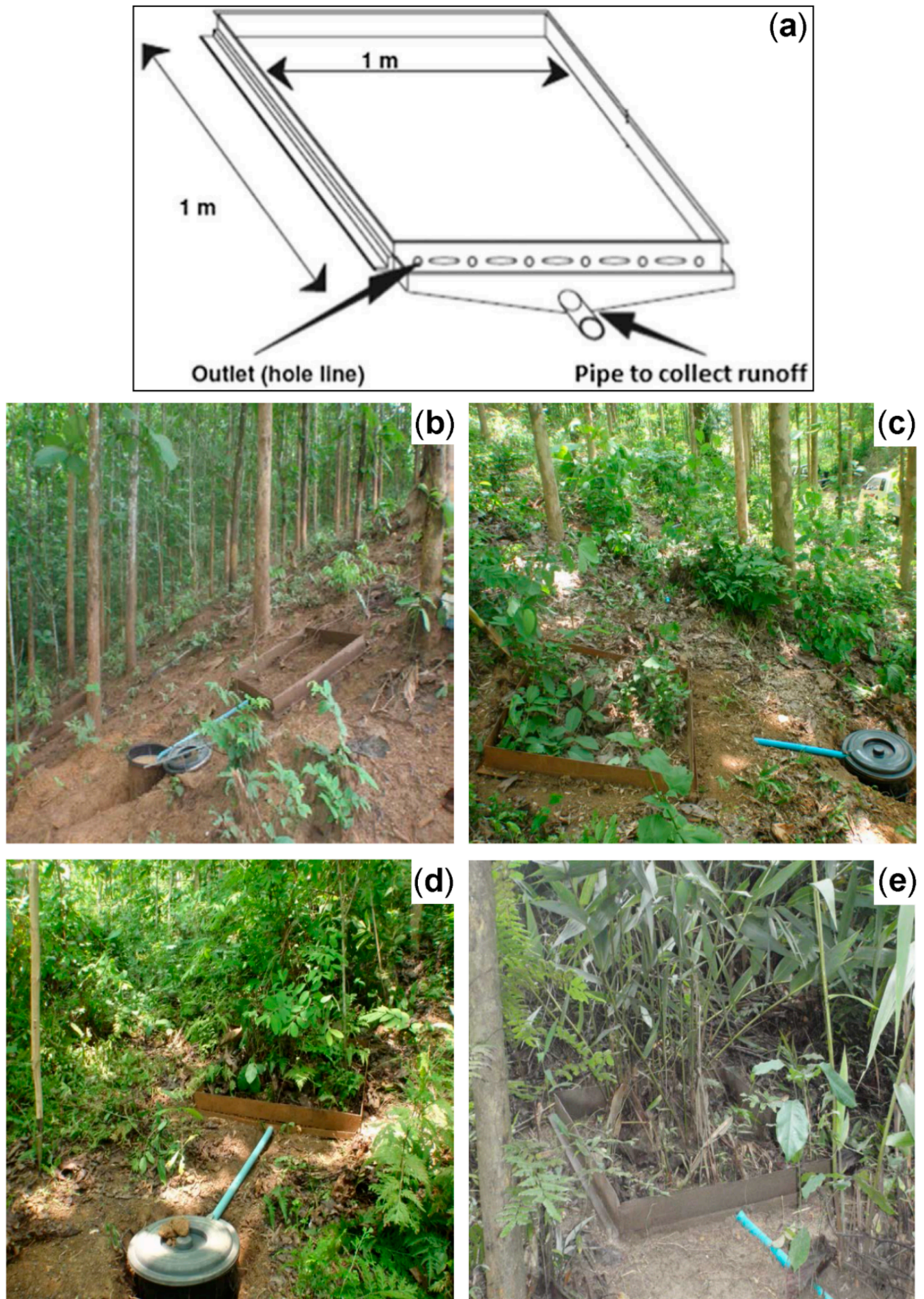

Figure 2. (a) Sketch of microplot of $1 \times 1 \mathrm{~m}$ metal frame connected to a bucket through a pipe for surface runoff and sediment collection (source: [31]). (b) Microplot of TNU: teak with no understory. (c) Microplot of TLU: teak with low density of understory. (d) Microplot of THU: teak with high density of understory. (e) Microplot of TBG: teak with broom grass. Microplots were installed on 9th and 10th of May 2017, in Ban Kokngew, Luang Prabang Province, Lao People's Democratic Republic. 


\subsection{Teak Trees and Understory Structure Assessment}

We measured teak tree height, canopy cover, and stem diameter at $1.6 \mathrm{~m}$ height in $10 \times 10 \mathrm{~m}$ plots enclosing the microplots. At the time of measurement, on 14 December 2017, i.e., during the dry season, some teak trees were already shedding their leaves (30\% and 35\% cover in TLU and TNU, respectively) but in other plantations, many teak leaves were still attached (70\% and $60 \%$ cover in THU and TBG, respectively). Average teak heights ranged from $20 \mathrm{~m}$ to $22 \mathrm{~m}$. Average diameter at $1.6 \mathrm{~m}$ height was $16 \mathrm{~cm}$. The original planting density had been 2000 tree $\mathrm{ha}^{-1}$ in TNU and TBG, from which the actual density was obtained by thinning $40 \%$ and $50 \%$, respectively. The original planting density had been 1600 tree $\cdot \mathrm{ha}^{-1}$ in THU and only 1200 tree $\mathrm{ha}^{-1}$ in TLU; here the actual densities were obtained by thinning $50 \%$ and $16 \%$, respectively (Table 1 ).

We considered two categories of understory: one consisting of weed and low vegetation, hereafter referred to as "understory" and another consisting of purposely planted broom grass (Thysanolaena latifolia) monocrop, hereafter referred to as "broom grass". Both kinds of understories are spontaneous vegetation, but farmers enhance broom grass propagation by cutting. The TBG treatment in this study was made of replanted broom grass. Farmers cut the inflorescences of broom grass to make brooms and regularly prune the grass. We described the structure of the understory in each of the four selected treatments during the 2017 rainy season by combining the use of visual inspections (percentage of cover assessment) and measuring tapes (girth, height). We estimated the mean understory height and cover in a representative area of $18 \mathrm{~m}^{2}$ encompassing the three microplot replicates on 4 June and 27 October 2017.

\subsection{Rainfall Measurements}

We measured rainfall by using a rain gauge (Campbell BWS200 equipped with ARG100, $0.2 \mathrm{~mm}$ capacity tipping-bucket; Figure 1).

\subsection{Surface Runoff, Soil Loss, and Soil Surface Features Assessment}

We collected surface runoff through a small channel at the lower side of each microplot, connected to a large plastic bucket by a plastic pipe (Figure 2a). The height of the buckets was $0.45 \mathrm{~m}$ while their diameter at the bottom was $0.32 \mathrm{~m}$ and the diameter at the top was $0.38 \mathrm{~m}$. We emptied the buckets after every major rainfall event, or after a series of two to ten smaller rainfall events. We calculated the runoff coefficient as the ratio between the total surface runoff depth and the total rainfall depth, expressed in percentage. We also computed a cumulated runoff coefficient over the rainy season.

Soil loss was the total weight of sediment collected each time the buckets were emptied. It was measured after flocculation, filtration, and oven dehydration. We calculated suspended sediment concentration by dividing sediment mass by surface runoff depth and we cumulated soil loss over the rainy season.

Soil surface features were assessed at the beginning ( 4 June) and at the end (27 October) of the rainy season using the method proposed by [48] and extensively used by $[23,26,28-33,44,49-54]$. We calculated the average of each soil surface feature for each treatment by first calculating the averages of the two measurements dates per treatment, and then by calculating the averages among the six replicates per treatment. Surface features include understory, residues (leaves, branches, seeds), constructions by soil macro-organisms like earthworms and termites, moss and algae, charcoals, free aggregates, free gravel, and three types of crust: structural, erosion, and gravel crusts. In these soils, structural crusts result from the packing of highly stable micro-aggregates [32,50]. Compacted by raindrops and smoothed by surface runoff, this structural crust gradually transforms into an erosion crust characterized by a thin and very compacted smooth plasmic layer [55]. When they include gravels, structural or erosion crusts become a gravel crust [51]. Additionally, we assessed the percentage areas of soil corresponding to pedestal features [5]. 


\subsection{Statistical Analysis and Modelling}

We performed non-parametric Wilcoxon tests (R version 3.5.3, The R Foundation for Statistical Computing) to compare the distribution between paired groups of the four treatments for three variables (surface runoff depth, suspended sediment concentration, and runoff coefficient).

We conducted a correlation analysis between the measured variables, namely Rc: seasonal runoff coefficient; Sl: seasonal soil loss; and soil surface features expressed in areal percentage: Fa: free aggregates; Fg: free gravel; Tc: total crust; Sc: structural crust; Ec: erosion crust; Gc: gravel crust; Cha: charcoals; Res; residues; Wor: worm casts; Alg: algae; Mos: mosses; Ped: pedestals; Und: understory. To meet the distributional and variance assumptions required for linear statistical models [56], we transformed the variables prior to the analysis; variables expressed in percent were normalized using the arcsine of the square root, which is a classical transformation for percentages, while Sl was scaled with logarithm transformation [31]. The main objective of these transformations was to make each distribution symmetrical. After transformation, we calculated Pearson correlation coefficients and significance levels (XLSTAT Premium version 20.1.1., Addinsoft, Paris, France) in order to test the correlation between variables.

We also calculated partial least squares regression (PLSR) analysis [57] on the measured variables (XLSTAT Premium version 20.1.1.) in order to model Rc and Sl depending on soil surface features: Fa: free aggregates; Fg: free gravel; Tc: total crust; Cha: charcoals; Res; residues; Wor: worm casts; Alg: algae; Mos: mosses; Ped: pedestals; Und: understory. PLSR has the advantage to be little sensitive to multi-collinearity and can be used with datasets where the number of observations is close to the number of variables, or even smaller. The importance of each projected variable is estimated by the variable importance in the projection number (VIP). In order to limit the uncertainty related to the variables that bring little information to the model, and consequently to limit the distortion of the results, we discarded the VIP values below $0.8[58,59]$.

\section{Results}

\subsection{Rainfall}

Accumulated rainy season rainfall was $1133 \mathrm{~mm}$ from 4 June to 15 October 2017. A total of 22 major rainfall events occurred during the same period (Figure S1). Minimum rainfall depth was $17 \mathrm{~mm}$ whereas maximum was $93 \mathrm{~mm}$. Average rainfall depth was $52 \mathrm{~mm}$. About $36 \%$ of the major rainfall events occurred in July, which represents $33 \%$ of the accumulated rainy season rainfall depth.

\subsection{Height and Cover of Teak Trees and of Understory}

The average height of the teak trees ranged from $20 \mathrm{~m}$ in THU and TBG to $22 \mathrm{~m}$ in TNU and TLU. Teak cover was $30 \%$ and $35 \%$ in TLU and TNU, respectively, and was $60 \%$ and $70 \%$ in TBG and THU, respectively. The average height of understory varied between $0.6 \mathrm{~m}$ in TNU and $4 \mathrm{~m}$ in TLU. Understory cover varied between $30 \%$ in TNU and $90 \%$ in THU (Figure 3).

\subsection{Soil Surface Features and Pedestal Features}

The average height of pedestal features ranged from $1.2 \mathrm{~cm}$ in TBG to $2.1 \mathrm{~cm}$ in TNU (Figure $4 \mathrm{a}, \mathrm{b}$ ). The pedestal features cover was high in TNU (50\%) compared to the other treatments (3-6\%; Figure $4 \mathrm{~b})$.

Figure $4 \mathrm{c}$ illustrates the percentage area of total crust (erosion crust, structural crust, and gravel crust), free aggregates, free gravel, charcoals, and residues in each treatment. Soil surface across the treatments excluding TNU shared similar conditions, such as total crust $(8.5 \%)$, free aggregates $(32.5 \%)$, and residues $(58.5 \%)$. On the contrary, TNU exhibited high total crust $(82.5 \%)$, free gravel $(9.3 \%)$, and little residues (2.91\%). Structural crust accounts for more than $90 \%$ of total crust in each treatment and charcoals are negligible (less than $0.03 \%$ ). Nevertheless, erosion crust was $0.54 \%$ in TNU, and negligible in the other three treatments (less than $0.05 \%$ ). 
Figure 5 shows the relationship between the percentage of cover of pedestal features and both surface runoff (logarithm model, $\mathrm{R}^{2}=0.82$ ) and soil loss (linear model, $\mathrm{R}^{2}=0.91$ ). The percentage of cover of pedestal features exhibits a consistent increase with increasing surface runoff and soil loss.

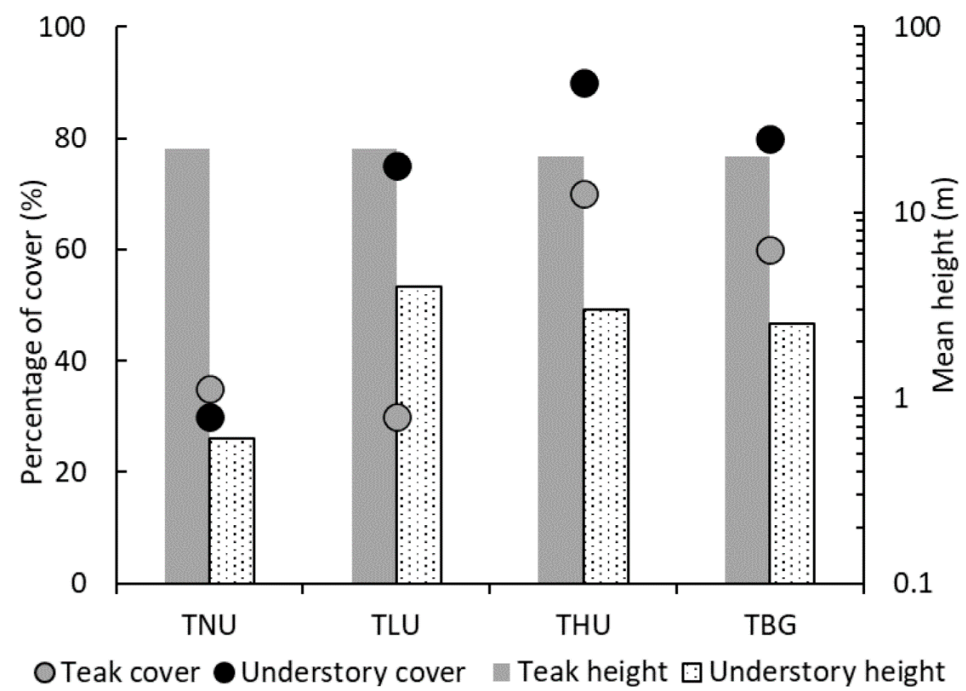

Figure 3. Percentage of cover (\%) by teak trees and understory, and mean height (m) of teak trees and understory in each treatment measured on 14 December 2017, in Ban Kokngew, Luang Prabang Province, Lao People's Democratic Republic. TNU: teak with no understory; TLU: teak with low density of understory; THU: teak with high density of understory; TBG: teak with broom grass.

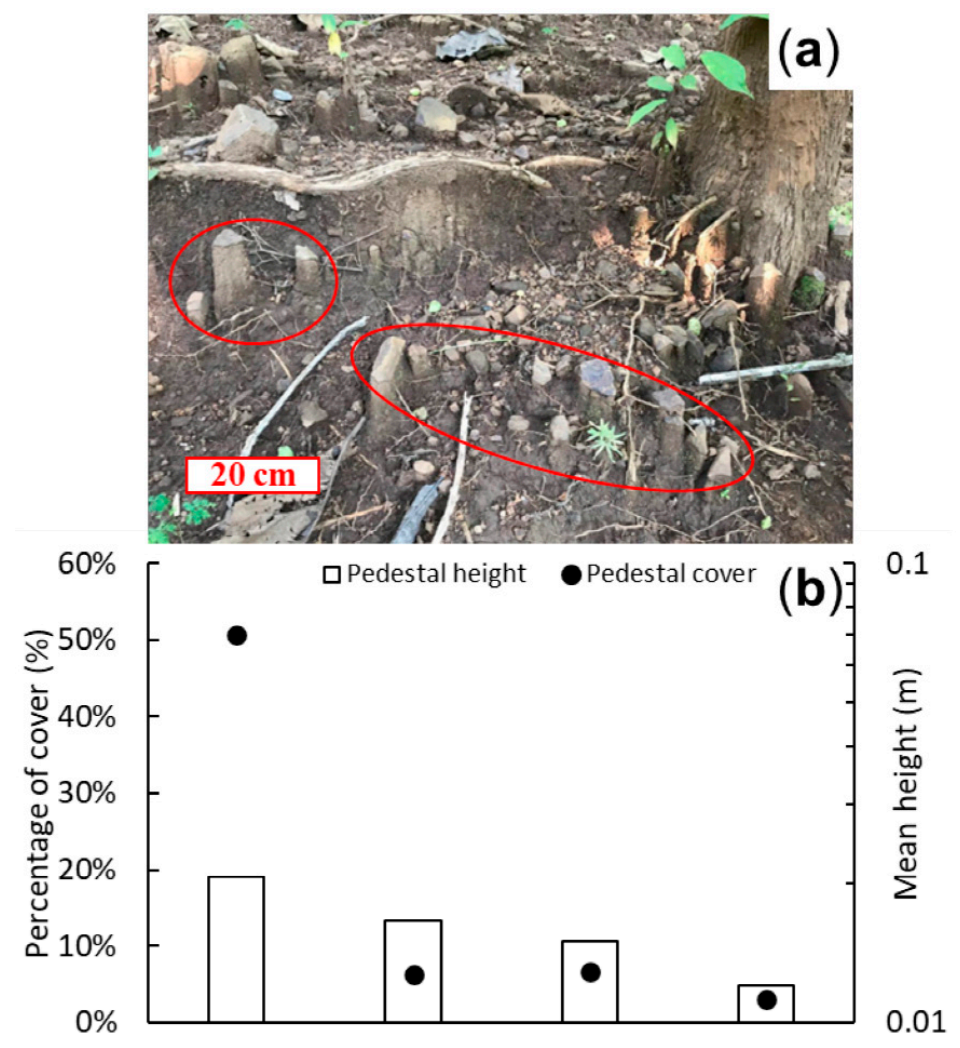

Figure 4. Cont. 


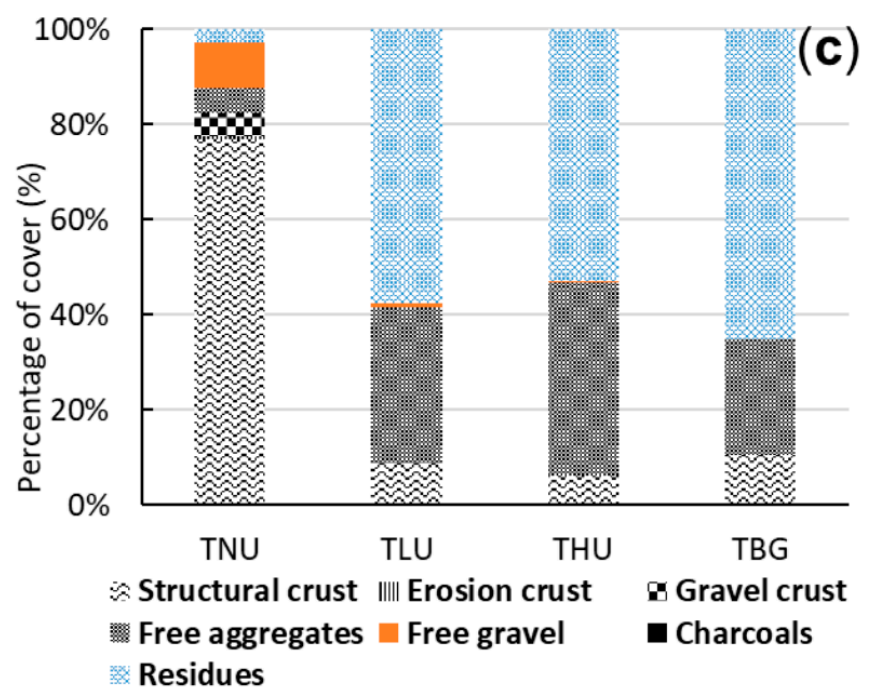

Figure 4. (a) Example of pedestal features circled by red lines. (b) Percentage of cover of pedestal features (\%) and pedestal features' height ( $\mathrm{m}$; logarithmic scale). (c) Cumulative percentage areas (\%) of the soil surface features in 2017 in Ban Kokngew, Luang Prabang Province, Lao People's Democratic Republic. TNU: teak with no understory; TLU: teak with low density of understory; THU: teak with high density of understory; TBG: teak with broom grass.

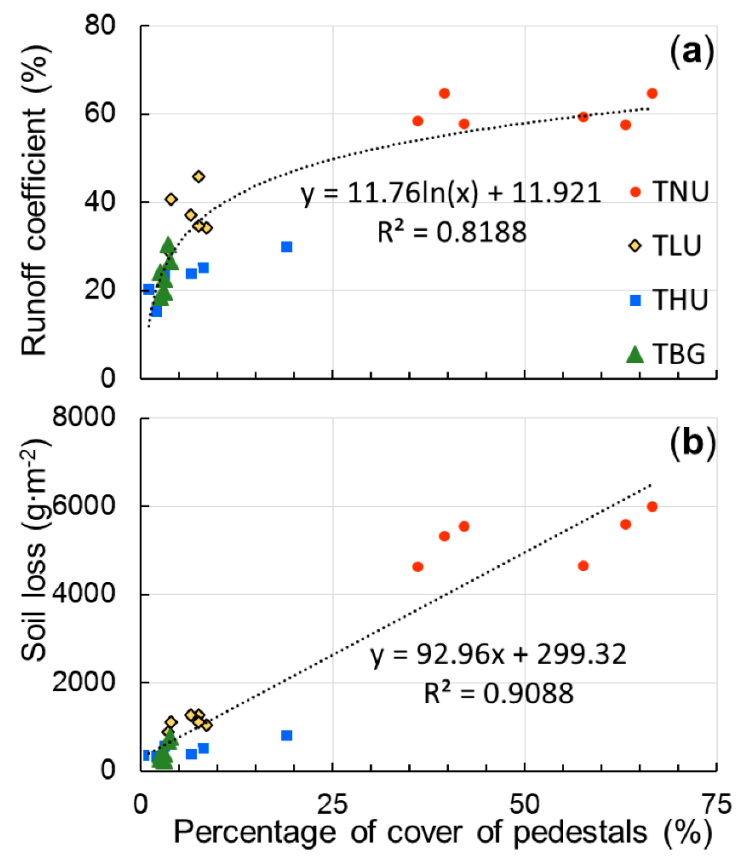

Figure 5. (a) Relationship between runoff coefficient (\%) and percentage of cover of pedestal features (\%). (b) Relationship between soil loss $\left(\mathrm{g} \cdot \mathrm{m}^{-2}\right)$ and percentage of cover of pedestal features (\%) measured in 2017 in Ban Kokngew, Luang Prabang Province, Lao People's Democratic Republic. TNU: teak with no understory; TLU: teak with low density of understory; THU: teak with high density of understory; TBG: teak with broom grass.

\subsection{Relationship between Surface Runoff and Soil Loss across Four Treatments}

Figure 6 depicts the linear correlation between accumulated surface runoff and accumulated soil loss on log scale during the rainy season in 2017 for all the replicates. Total surface runoff averaged over the rainy season ranged from approximately $170 \mathrm{~mm}$ in THU and TBG to $480 \mathrm{~mm}$ in TLU, while it reached up to $680 \mathrm{~mm}$ in TNU. The average value in the four treatments was $370 \mathrm{~mm}$. TBG and THU 
provided the same amount of surface runoff. Soil loss varied between $249 \mathrm{~g} \cdot \mathrm{m}^{-2}$ in TBG to $6012 \mathrm{~g} \cdot \mathrm{m}^{-2}$ in TNU, with an average of $1848 \mathrm{~g} . \mathrm{m}^{-2}$ in all treatments. The highest sediment concentration was $9.60 \mathrm{~g} \cdot \mathrm{L}^{-1}$ in TNU, while the other three treatments had an average of $2.34 \mathrm{~g} \cdot \mathrm{L}^{-1}$.

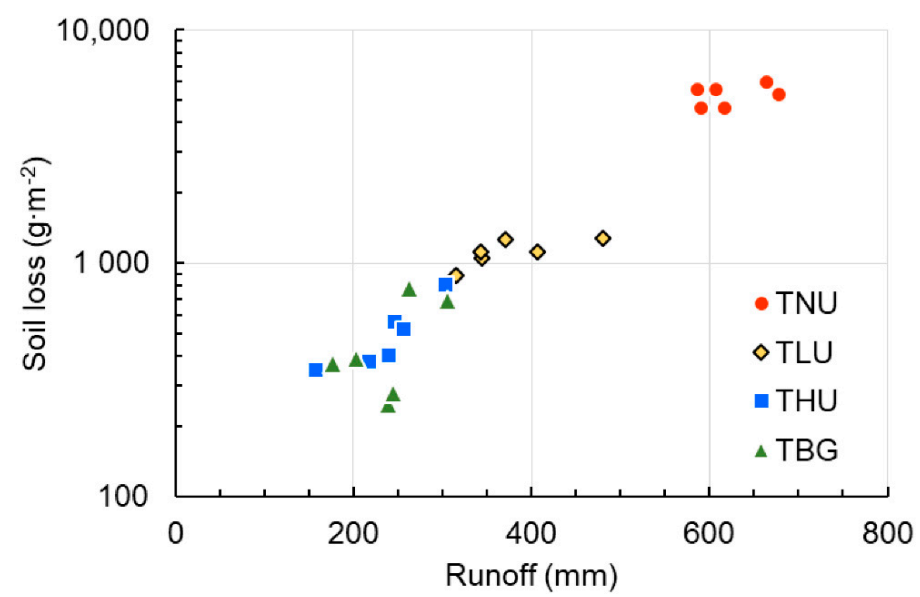

Figure 6. Surface runoff $(\mathrm{mm})$ and soil loss (g.m ${ }^{-2}$, logarithmic scale) measured from 4 June to 15 October 2017, in the four treatments with six replicates in Ban Kokngew, Luang Prabang Province, Lao People's Democratic Republic. TNU: teak with no understory; TLU: teak with low density of understory; THU: teak with high density of understory; TBG: teak with broom grass.

\subsection{Effect of Understory on Soil Loss and Surface Runoff Generation}

The Wilcoxon test applied to the cumulative surface runoff, the average suspended sediment concentration, and the runoff coefficient for the four treatments highlighted three significantly ( $p$-value $>0.05$ ) different categories of treatments: from the little erosive treatments (THU and TBG) to highly erosive treatments (TNU; Figure 7).

The surface runoff pattern matched the rainfall pattern, while the soil detachment pattern did not perfectly match rainfall pattern (Figure S1). The highest median values of surface runoff and runoff coefficient (44 mm mostly in TNU and about $110 \%$ in TBG and TNU, respectively) were observed from 15 July to 15 August and this pattern was less clear for soil loss. We found the maximum median value of soil loss in TNU ( $551 \mathrm{~g} \cdot \mathrm{m}^{-2}$ ). For one replicate of TNU, the soil loss reached $1054 \mathrm{~g} \cdot \mathrm{m}^{-2}$ (8 July).

Figure $\mathrm{S} 2$ shows the cumulative surface runoff and cumulative soil loss in relation to cumulative rainfall over the 2017 rainy season for the different treatments. Surface runoff and soil loss in TBG were $242 \mathrm{~mm}$ and $381 \mathrm{~g} \cdot \mathrm{m}^{-2}$, respectively. Surface runoff and soil loss in THU were $242 \mathrm{~mm}$ and $465 \mathrm{~g} \cdot \mathrm{m}^{-2}$, respectively. Surface runoff and soil loss in TLU were $358 \mathrm{~mm}$ and $1115 \mathrm{~g} \cdot \mathrm{m}^{-2}$, respectively. TNU produced more surface runoff $(612 \mathrm{~mm})$ and much more soil loss $\left(5455 \mathrm{~g} \cdot \mathrm{m}^{-2}\right)$ than the other treatments. Hence, the surface runoff in TNU was approximately 2.5-times higher than in THU and TBG, and 1.7-time higher than in TLU. The soil loss in TNU was 13- and 14-times higher than in THU and TBG, respectively. TNU had the sharpest rise of soil loss among all the treatments. Median runoff coefficients for TBG, THU, TLU, and TNU were $23 \%, 23 \%, 25 \%$, and $60 \%$, respectively.

\subsection{Runoff Coefficient and Soil Loss in Relation to Soil Surface Features and Understory Cover}

Table 2 shows the relationship between the surface runoff coefficient, soil loss, and soil surface features areal percentages. Erosion crust, charcoals, worm casts, algae, and mosses show weak correlations with the surface runoff coefficient while the other soil surface features and understory cover provided Pearson correlation coefficient ( $r$ ) above 0.7. The features with lower $r$ had lower percentages, which may cause poor relation with the surface runoff coefficient. Free aggregates, residues and understory had a strong and negative correlation with surface runoff with $\mathrm{r}$ between -0.72 and -0.91 . Free gravel, total crust, structural crust, gravel crust, and pedestal features cover exhibited a strong correlation with surface runoff $(r=0.84,0.89,0.89,0.98$, and 0.89 , respectively). 
We also found a strong correlation between soil loss and surface runoff $(r=0.97)$. Soil surface features and understory cover exhibited significant inter-correlation except for charcoals, worm casts, algae, and mosses, which were weakly related to other types of soil surface features or understory cover.
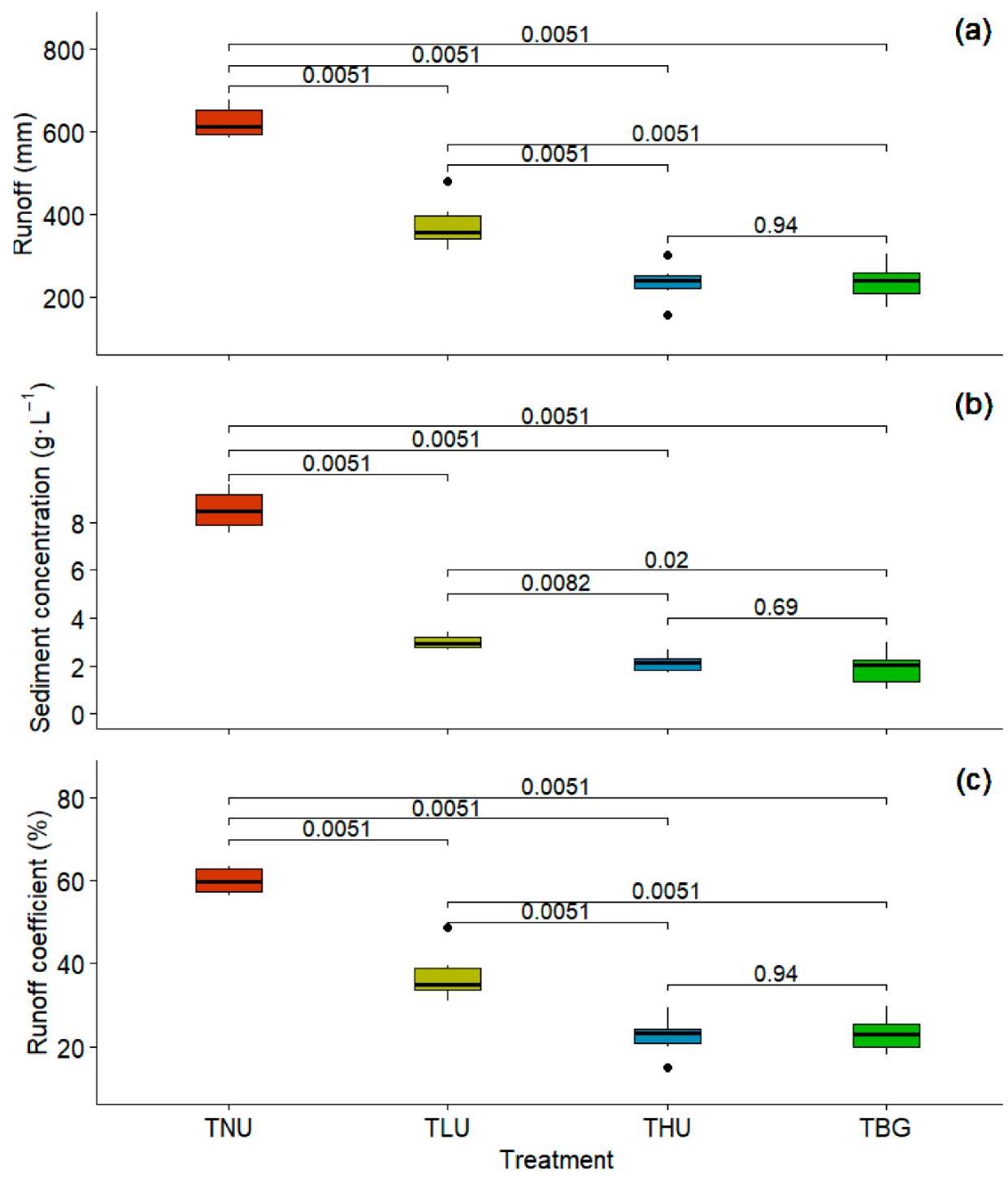

Figure 7. Boxplots of (a) cumulative surface runoff $(\mathrm{mm}),(\mathbf{b})$ average suspended sediment concentration $\left(\mathrm{g} \cdot \mathrm{L}^{-1}\right)$, and (c) runoff coefficient (\%) in each treatment measured from 4 June to 15 October 2017, in Ban Kokngew, Luang Prabang Province, Lao People's Democratic Republic. Each rainfall bar represents the accumulated rainfall over the period prior to the sampling. Each boxplot contains the extreme of the lower whisker (vertical line), the lower hinge (thin line), the median (bold line), the upper hinge (thin line), the extreme of the upper whisker (vertical line), and the outliers (black dots) with $p$-values from Wilcoxon tests between two groups of treatments. The whiskers extend to the most extreme data point, which is no more than 1.5-times the interquartile range from the box. TNU: teak with no understory; TLU: teak with low density of understory; THU: teak with high density of understory; TBG: teak with broom grass. The runoff coefficient is the ratio in percentage between total surface runoff depth and total rainfall depth. 
Table 2. Correlation (Pearson coefficient) between seasonal runoff coefficient (Rc), seasonal soil loss (Sl), and soil surface features: Fa: free aggregates; Fg: free gravel; Tc: total crust; Sc: structural crust; Ec: erosion crust; Gc: gravel crust; Cha: charcoals; Res; residues; Wor: worm casts; Alg: algae; Mos: mosses; Ped: pedestals; Und: understory. All variables were measured in 2017 in Ban Kokngew, Luang Prabang Province, Lao People's Democratic Republic.

\begin{tabular}{|c|c|c|c|c|c|c|c|c|c|c|c|c|c|c|}
\hline Variables & Rc & S1 & Fa & Fg & Tc & Sc & Ec & Gc & Cha & Res & Wor & Alg & Mos & Ped \\
\hline S1 & $0.97^{* * * *}$ & & & & & & & & & & & & & \\
\hline Fa & $-0.72^{* * * *}$ & $-0.77^{* * * *}$ & & & & & & & & & & & & \\
\hline Fg & $0.84^{* * * *}$ & $0.86^{* * * *}$ & $-0.72^{* * * *}$ & & & & & & & & & & & \\
\hline Tc & $0.89^{* * * *}$ & $0.90^{* * * *}$ & $-0.87^{* * * *}$ & $0.84^{* * * *}$ & & & & & & & & & & \\
\hline Sc & $0.89 * * * *$ & $0.90^{* * * *}$ & $-0.87^{* * * *}$ & $0.83^{* * * *}$ & $0.99 * * * *$ & & & & & & & & & \\
\hline Ec & $0.62^{* *}$ & $0.64^{* * *}$ & $-0.58^{* *}$ & 0.44 * & $0.67^{* * *}$ & $0.66^{* * *}$ & & & & & & & & \\
\hline Gc & $0.87^{* * * *}$ & $0.90^{* * * *}$ & $-0.78^{* * * *}$ & $0.90^{* * * *}$ & $0.91^{* * * *}$ & $0.90^{* * * *}$ & $0.70^{* * *}$ & & & & & & & \\
\hline Cha & 0.48 * & 0.44 * & -0.39 & 0.32 & $0.52 * *$ & $0.52 * *$ & 0.49 * & 0.43 * & & & & & & \\
\hline Res & $-0.87^{* * * *}$ & $-0.89^{* * * *}$ & $0.77^{* * * *}$ & $-0.88^{* * * *}$ & $-0.97^{* * * *}$ & $-0.97^{* * * *}$ & $-0.66^{* * *}$ & $-0.94^{* * * *}$ & -0.53 ** & & & & & \\
\hline Wor & -0.47 * & $-0.42 *$ & -0.07 & $-0.46^{*}$ & -0.27 & -0.27 & -0.15 & -0.37 & -0.13 & 0.39 & & & & \\
\hline Alg & $0.55^{* *}$ & 0.53 ** & -0.31 & 0.49 * & $0.45^{*}$ & 0.45 * & 0.16 & 0.44 * & 0.28 & $-0.47^{*}$ & -0.23 & & & \\
\hline Mos & -0.26 & -0.34 & 0.27 & -0.25 & -0.39 & -0.38 & -0.32 & -0.37 & -0.10 & 0.42 * & 0.26 & -0.13 & & \\
\hline Ped & $0.89^{* * * *}$ & $0.91^{* * * *}$ & $-0.80^{* * * *}$ & $0.82^{* * * *}$ & $0.94^{* * * *}$ & $0.94^{* * * *}$ & $0.73^{* * * *}$ & $0.91^{* * * *}$ & $0.54^{* *}$ & $-0.92^{* * * *}$ & -0.30 & 0.38 & -0.31 & \\
\hline Und & $-0.91^{* * * *}$ & $-0.93^{* * * *}$ & $0.89^{* * * *}$ & $-0.86^{* * * *}$ & $-0.98^{* * * *}$ & $-0.98^{* * * *}$ & $-0.63^{* *}$ & $-0.91^{* * * *}$ & $-0.49^{*}$ & $0.95^{* * * *}$ & 0.26 & $-0.47^{*}$ & 0.36 & $-0.92^{* * * *}$ \\
\hline
\end{tabular}

Significance level: ${ }^{* * * *} p<0.0001 ;{ }^{* * *} p<0.001 ;^{* *} p<0.01 ;{ }^{*} p<0.05$. 
Figure 8a shows PLSR biplot of inter-correlation between runoff coefficient, soil loss, understory, and soil surface features. The runoff coefficient and soil loss were positively correlated with total crust, pedestal features cover, free gravel, charcoals, and algae, but were negatively correlated with understory, residues, and free gravel. Worm casts and mosses had no significant relation with the other variables.
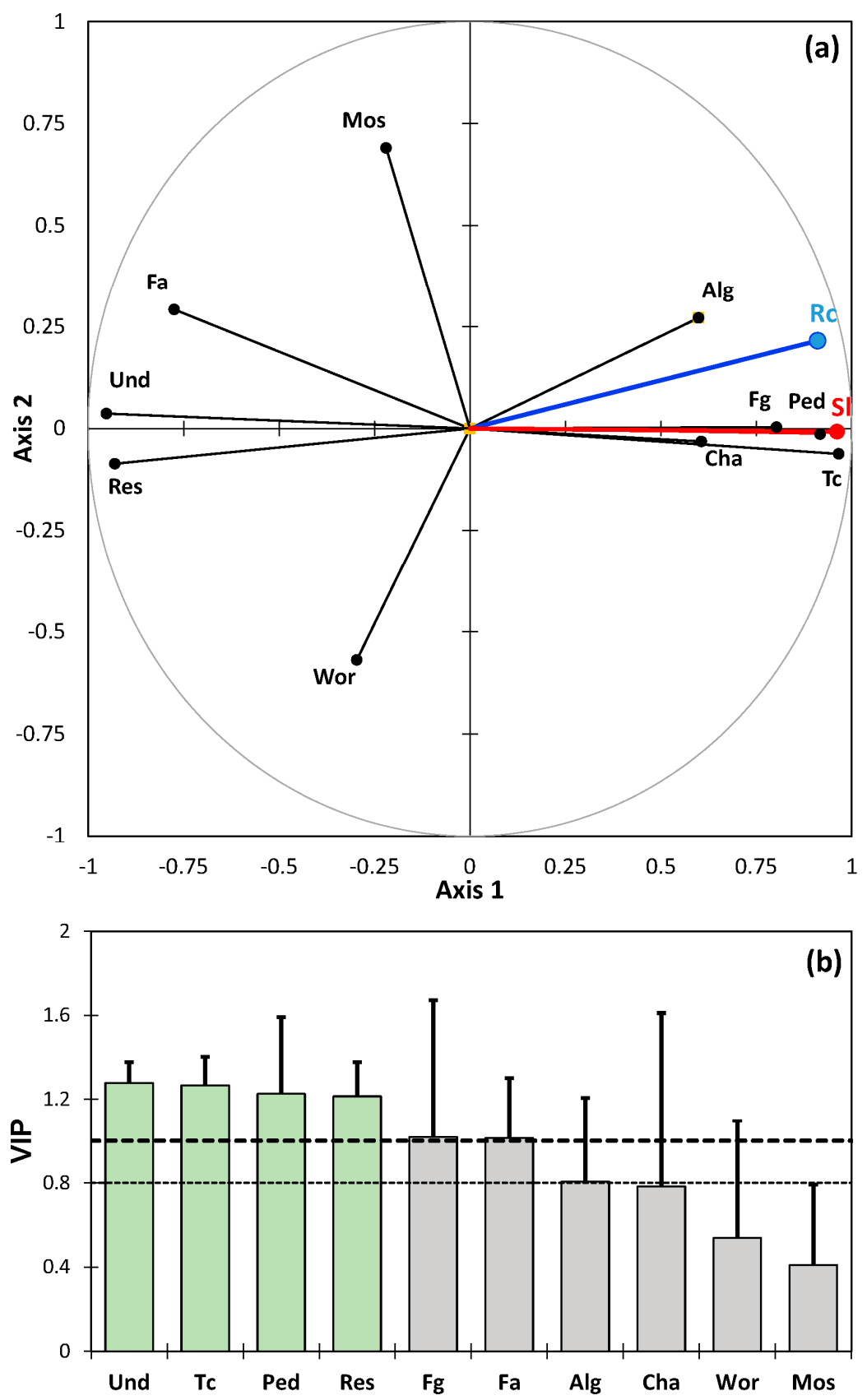

Figure 8. (a) Partial least squares regression (PLSR) biplot for seasonal surface runoff coefficient (Rc) and seasonal soil loss (Sl) in relation with soil surface features and understory. (b) Variable importance for the projection (VIP) score plot of each variable contributing the most to the models of Rc and Sl. Und: understory; Tc: total crust; Ped: pedestals; Res; residues; Fg: free gravel; Fa: free aggregates; Alg: algae; Cha: charcoals; Wor: worm casts; Mos: mosses. All variables were measured in 2017 in Ban Kokngew, Luang Prabang Province, Lao People's Democratic Republic.

Figure $8 \mathrm{~b}$ displays the score plot of variable importance in projection (VIP) for each soil surface feature and understory treatment. This plot allows the rapid identification of the variables that 
contribute the most to the models of runoff coefficient and soil loss (Figure S3). Understory, total crust, pedestal features cover, and residues, were considered the most important variables and therefore the best predictors in the model. The coefficients of each variable contributing to the models' equation are listed in Table S1.

Figure 9 shows the observed and the modelled soil loss proposed by [31]. The soil loss is a function of the runoff coefficient with the equation $\ln (\mathrm{Sl})=-1.30+2.36 \ln (\mathrm{Rc})$, where $\mathrm{Sl}$ is the soil loss and $R c$ is the runoff coefficient. The model provided significant statistics $\left(R^{2}=0.91, p<0.0001\right)$ and is a promising framework for the prediction of soil loss based on the runoff coefficient.

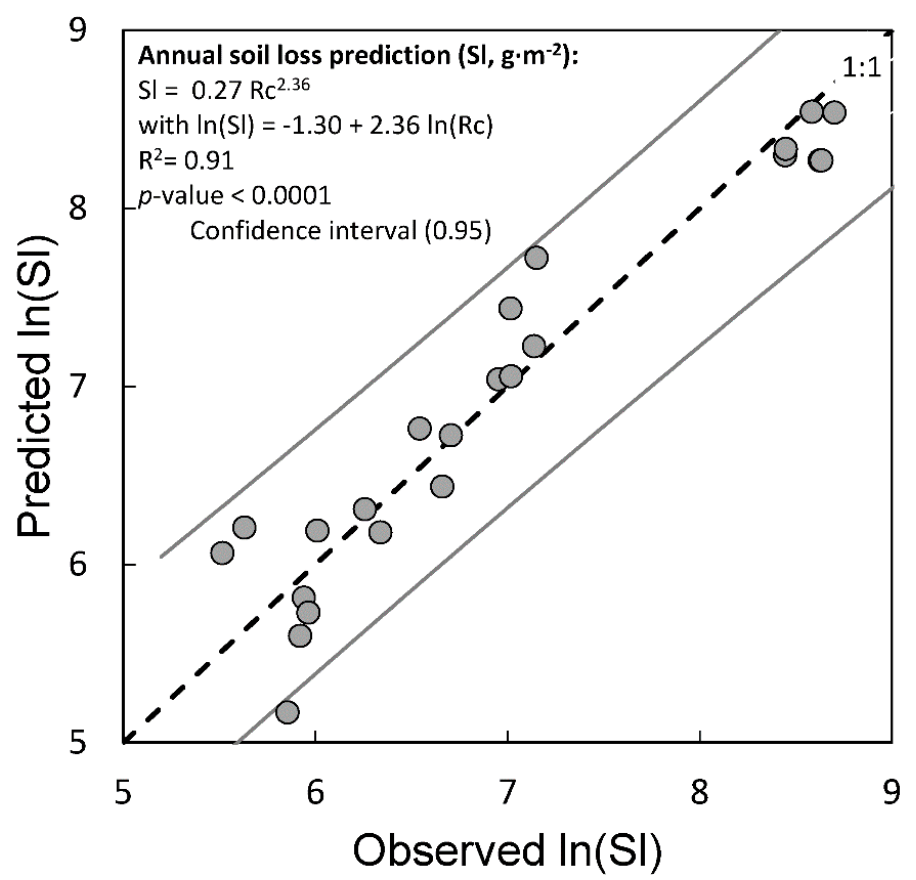

Figure 9. Observed and modelled seasonal soil loss. Each point represents the seasonal soil loss of the 24 microplots. Values (in $\mathrm{g} \cdot \mathrm{m}^{-2}$ ) were predicted using the simple formulation $\ln (\mathrm{Sl})=-1.30+2.36$ $\ln (\mathrm{Rc})$, where Rc is the seasonal runoff coefficient and $\mathrm{Sl}$ is the seasonal soil loss, as proposed by [31]. Observed Rc and Sl were measured from 4 June to 15 October 2017, in Ban Kokngew, Luang Prabang Province, Lao People's Democratic Republic.

\section{Discussion}

\subsection{Understory Limits Surface Runoff and Soil Erosion}

Soil loss is strongly related to surface runoff (Figures 6 and 8, and Table 2). Soil loss increased with increasing surface runoff, especially in TNU, which produced the most surface runoff, over the rainy season (Figure S1). Patin et al. [31] successfully applied the Terrace Erosion and Sediment Transport (TEST) model developed by [43] to estimate soil detachment observed for various land covers in the Houay Pano catchment, northern Lao PDR. They also proposed a simple soil loss model describing the soil loss as a function of the runoff coefficient. We applied this simplified model and also found that seasonal surface runoff coefficient is a reliable predictor of the seasonal soil loss (Figure 9). This result shows that, at the plot scale, surface runoff is statistically the main process responsible for the transfer of solid particles. Our results show that under the studied conditions, sediment production, which is high, is not the limiting factor to soil loss. We found that soil loss had a strong correlation with structural crust and a strong negative correlation with free aggregates and residues. Overall, these findings are in accordance with the findings reported by [30], namely that soil loss increases with an increasing surface runoff coefficient proportionally predicted by structural crust. The percentage of erosion crust is one of the main drivers of soil erosion [30]. At the plot scale, soil detachment firstly depends on 
splash [5]. The packing of the soil particles, which is due to the compaction by large drops, leads to crust forming [5]. Soil detachment by splash eventually leads to pedestal features [5]. We found that the structural crust represents in average $93-100 \%$ of the total crust, similar to the $91 \%$ reported by [30] for mature teak trees. Consistently, the percentage of pedestal features cover (Figure 4a) and total crust ( $82 \%$ of the percentage area of soil surface feature; Figure $4 \mathrm{~b}$ ) was relatively high in TNU. The highest surface runoff and soil loss were observed in TNU, due to the highly crusted area together resulting from less residues cover and the absence of understory cover. Hence, runoff generation occurs on the crusted soil area which restricts infiltration $[60,61]$, depending on the presence of plant residues at soil surface and understory [62,63]. Residues do not only prevent crust formation [62], but also favor the biological activity of organisms which decompose organic matter from the residues, especially macro-faunal communities (also referred to as soil engineers) [64]. This biological process contributes to increase the infiltration rate through the development of soil biological porosity and breakdown of soil crusts resulting from previous inappropriate land use $[63,65]$. The surface runoff coefficient is a function of structural crust [30] and our results confirmed this finding (Table 2). A similar result was obtained by $[61,66,67]$ who found that a soil crusted area enhances surface runoff and soil erosion. Crusted soil has less influence on soil detachment due to its physical protection [33]. This implies that structural crust is not the main cause of soil erosion but the main driver of surface runoff generation [30]. Once generated, surface runoff carries towards downstream the soil particles detached by splash [5].

Our models based on PLSR analysis confirmed the importance of each soil surface feature, including understory cover, in predicting seasonal surface runoff coefficient and seasonal soil loss at the plot scale (Figure S3 and Table S1). High soil detachment and surface runoff could be alleviated by the physical protection of both understory covers, including broom grass, and plant residues (originating from teak leaves and understory). Soil splash depends on understory cover and on the percentage of cover by residues [5], while surface runoff decreases when understory cover increases [68]. The understory and a thick residue layer reduces the rain splash effect and allows a high rate of infiltration, which then reduces surface runoff and soil erosion [69]. The soil is protected by understory, which dissipates the high raindrops' kinetic energy under teak trees [5]. In the absence of understory, the height of trees plays a decisive role with respect to soil detachment (Figure 3). Tall tree canopy in dense tree plantations intercepts the raindrops. Since teak tree leaves are broad, leaves dramatically increase the diameter of raindrops with throughflow, hence their kinetic energy and erosivity $[27,30,70]$. Plant residue attenuates the effect of rain splash and reduces the percentage area of total crust [30]. A number of authors have shown that the removal of understory by slashing and burning induces increased surface runoff and soil erosion [52,65,71,72].

Runoff coefficients in the four treatments varied in time and increased in the middle of the rainy season (July 2017, Figure S1), which is explained by antecedent rainfall, i.e., the rain falling before any rainfall event of interest [73]. Rainfall events happen more frequently in the middle of the rainy season. Since there is less time between two subsequent rainfall events to dry the soil, soil moisture increases, and soils get saturated or nearly saturated by water. Consequently, surface runoff generation is enhanced, and the runoff coefficients increase in the middle of the rainy season. Surface runoff in TNU plots were much higher than in all other treatments over the rainy season (Figure S1). The runoff coefficient in TNU was higher than in the other treatments since the very beginning of the season despite the low soil moisture and the low hydraulic conductivity of soil. Overall, the runoff coefficient in TNU was the highest with 59.7\% (Figure S2), which is comparable to the values found by [30] in mature teak tree plantations with similar conditions of understory. On the contrary, the runoff coefficients of THU and TBG were around 23\% (Figure S2), which is comparable to the overall runoff coefficient calculated for the treatments associating young teak trees with a variety of understory in [30].

The least erosive treatment in this study, i.e., TBG $\left(381 \mathrm{~g} \cdot \mathrm{m}^{-2}\right)$, produced soil loss about 7.5-times higher than the broom grass treatment in Houay Dou catchment in northern Lao PDR [30]. The difference between our finding and broom grass treatment in [30] can be explained by the lower residue cover 
and the greater height of teak trees in our study, and by the fact that broom grass canopy was less dense because it was grown under the shadow of the teak trees and frequently harvested. Our values in TBG treatment were also greater than the values reported by $[66,74]$ in northern Vietnam, with similar understory, topography, and climate, but with different vegetation types, namely mixed tree plantation and fallow, respectively. Similarly, the most erosive treatment in this study, i.e., TNU $\left(5455 \mathrm{~g} \cdot \mathrm{m}^{-2}\right)$, produced soil loss about 3.5-times higher than the mature teak tree treatment in [30]. The values in TNU were also higher than the values reported by $[30,33,66]$ in the same region with similar understory conditions. Such discrepancies may be related to soil surface conditions or plant and understory characteristics (height, plant density, percentage of cover), which were usually discussed in this study. However values 5.4-times higher were measured by [75] in Costa Rica, where antecedent land use as rangeland most likely greatly and durably reduced soil hydraulic conductivity [72]. Overall, the soil loss in TBG was 14-times less than in TNU. Hence, teak tree plantation owners could divide soil loss by 14 by keeping understory, such as broom grass, within teak tree plantations.

Considering the finding of our study at the plot scale, the farmers would also have saved about 40-50 ton $\cdot \mathrm{ha}^{-1}$ of soil over the 2017 rainy season if they had grown understory under teak trees. However, this result must be qualified since the value cannot be extrapolated at scales larger than the plot scale, such as the catchment scale, because erosion processes at catchment scale are different (suspended sediments deposition or resuspension, gully formation on steep slope). At the catchment scale, a supplementary mitigation measure to trap water and eroded soil particles before entering the river network would be riparian buffers and vegetation filter strips $[54,76]$.

\subsection{Broom Grass Grown in Teak Tree Plantations: Agronomic Aspects and Ecosystem Services}

Tree spacing is a determinant factor of teak tree productivity [65]. In our study, densities of 800-1200 tree $\cdot \mathrm{ha}^{-1}$ [47] (Table 1) were relatively high compared to densities reported for other plantation areas $\left(<800\right.$ tree $\left.\mathrm{ha}^{-1}\right)[65,77,78]$. Planting trees at lower densities in our study site should be seriously considered as not only would it warrant higher productivity [65], possibly higher than in natural forest $\left(40\right.$ tree $\left.\mathrm{ha}^{-1}\right)$ [77], but it would also allow growing intercropped understory adding economic value to the overall plantation yield.

The introduction of agroforestry into agricultural practices ensures an increased food security by a restored soil fertility for food crops [79] and a sustainable production of wood [64]. Broom grass is neither a food nor a feed crop but similar to agroforestry systems, it is grown under trees. Thus, the management practice may possibly increase the overall productivity (biomass, economic yield [45,47]) of the plot, by making an optimal use of the resources (water and nutrients), that would otherwise not be utilized by a single crop, consumed by plant species at different soil layers depending on their root length [80]. Although it seems to be more productive when grown in full light [30], broom grass can be grown under teak trees, similar to other shade-tolerant crops, such as patchouli [78].

Growing broom grass in teak tree plantations may supply a range of ecosystem services that is not limited to the supply of raw material for brooms and to the prevention of high surface runoff and soil loss in teak tree plantations. At the plot scale, the litter from broom grass leaves may increase top soil organic matter content [64], thus improving soil structure, soil nutrient availability [65], soil carbon sequestration [81], and increasing water infiltration and soil moisture retention [44,63]. Diversifying vegetation strata may diversify the habitats for bird species and other forest-dependent species $[77,82,83]$, thus increasing predator biodiversity $[84,85]$ and reducing the need for chemical inputs (insecticides, herbicides, etc.) in e.g., surrounding annual crop plots. At the catchment scale, favoring water infiltration and reducing surface runoff may mitigate natural disasters (floods and droughts) $[65,81]$ and increase the transfer time of contaminants deposited at the soil surface [86]. Decreasing the sediment supply to the stream network would increase the life span of dam reservoirs [87] and avoid dredging costs [88-90], an issue of particular concern along the Mekong River where the number of dams is dramatically increasing [91,92]. 


\subsection{Percentage of Cover of Pedestal Features: An Indicator of Soil Erosion}

Both the PLSR model and the simplified model proposed by [31] that we presented in this study provided promising results to predict soil loss. Nevertheless, such models require input data from experimental microplots which are rather difficult and time consuming to be implemented, particularly within the framework of a large-scale approach. It would be more practical to use simple indicators that are known to be proxies of soil loss, such as soil surface features and/or understory characteristics (Table 2). On one hand, understory cover varies throughout the year, which causes difficulties in visual observation and inconsistent estimation. On the other hand, observing soil surface features (such as total crust, free aggregates, free gravel, residues, etc.) requires some expertise. However, among soils surface features, pedestal feature cover is a reliable proxy of soil erosion intensity in the field (Figure 4a) that is easy to assess visually. Hence, lay people could use the proxy of the percentage of cover of pedestal features to identify the impact of the agricultural management of their land on soil degradation through surface runoff and soil loss.

\section{Conclusions}

We investigated the impact of different types of understory on surface runoff and soil loss in a teak tree plantation of the mountainous region of northern Lao PDR. We analyzed the relationship between understory management, soil surface features (including pedestal features), and surface runoff and soil loss at the plot scale. This paper clearly demonstrates that teak tree plantations, especially in steep sloping lands, can be prone to considerable soil loss if not properly managed. Our main findings, which are graphically synthesized in Figure 10, are that:

- Understory cover acts as an umbrella that protects soil surface from rain splash despite the height of teak trees and the large size of their leaves which contribute to produce raindrops of high kinetic energy. Teak tree plantation owners could divide soil loss by 14 by keeping understory, such as broom grass, within teak tree plantations. Hence, growing understory under teak trees is a mitigation management practice that can be reliably promoted to limit surface runoff and soil erosion.

- Residues from both teak tree leaves and understory not only protect the soil but also enhance the infiltrability of water into the soil. In contrast, the main driver of surface runoff and soil erosion is the percentage of crusted area.

- Understory such as broom grass provides several benefits to the relevant stakeholders in the area, in terms of incomes and ecosystem services. For example, the farmers can sell the brooms made from broom grass.

- The percentage of cover of pedestal features appears as a good indicator of soil erosion that farmers and teak tree plantations owners could easily use to assess the degradation of their land.

In such a context, to minimize surface runoff and soil erosion in steep slope areas such as the montane regions of south-east Asia, decision makers should, if not legally enforce the maintenance of understory strata in teak tree plantation, at least recommend the plantations owners to maintain understory and avoid understory and plant residue layers burning.

At the plot scale, our findings are relevant to farmers concerned about soil loss and soil fertility in their teak tree plots. At catchment scale, they are relevant to decision makers concerned with the management of costs (such as the cost of water treatment, and/or infrastructure rehabilitation such as dam reservoir dredging) resulting from soil loss induced by upslope activities such as tree plantations and improper agricultural land management. In addition to maintaining the understory strata, encouraging the use of e.g., riparian zone buffers along the streams $[93,94]$ could also be recommended to trap soil particles from the cultivated hillslopes and favor runoff infiltration, and thus ensure the sustainability of the system. 


\begin{tabular}{|l|c|c|c|}
\hline $\begin{array}{l}\text { Surface runoff \& Soil loss } \\
\text { Infiltration }\end{array}$ \\
\hline \multicolumn{2}{|c|}{ Soil profile } \\
Soil crusting \\
\hline
\end{tabular}

Figure 10. Graphical abstract. TNU: teak with no understory; TLU: teak with low density of understory; THU: teak with high density of understory; TBG: teak with broom grass.

Supplementary Materials: The following are available online at http://www.mdpi.com/2073-4441/12/9/2327/s1, Figure S1: (a) Cumulated rainfall (mm). (b) boxplots of runoff coefficient (\%). (c) boxplot of surface runoff (mm). (d) boxplot of soil loss $\left(\mathrm{g} \cdot \mathrm{m}^{-2}\right)$ in each treatment measured from 4 June to 15 October 2017, in Ban Kokngew, Luang Prabang Province, Lao People's Democratic Republic. TNU: teak with no understory; TLU: teak with low density of understory; THU: teak with high density of understory; TBG: teak with broom grass. Each rainfall bar represents the accumulated rainfall over the period previous to the sampling. Each boxplot contains the extreme of the lower whisker (dashed line), the lower hinge (thin line), the median (bold line), the upper hinge (thin line), and the extreme of the upper whisker (dashed line). The whiskers extend to the most extreme data point, which is no more than 1.5-times the interquartile range from the box. Figure S2: (a) Cumulative surface runoff (mm) versus cumulative rainfall and runoff coefficient (\%, total surface runoff divided by total rainfall), and (b) cumulative soil loss $\left(\mathrm{g} \cdot \mathrm{m}^{-2}\right)$ versus cumulative rainfall $(\mathrm{mm})$, measured from 4 June to 15 October 2017, in Ban Kokngew, Luang Prabang Province, Lao People's Democratic Republic. TNU: teak with no understory; TLU: teak with low density of understory; THU: teak with high density of understory; TBG: teak with broom grass. Figure S3: Observed and modelled seasonal runoff coefficient (Rc; in \%) and seasonal soil loss (Sl; in g.m-2) from partial least squares (PLS) regression method. Observed Rc and Sl were measured from 4 June to 15 October 2017, in Ban Kokngew, Luang Prabang Province, Lao People's Democratic Republic. Table S1: Coefficients of each variables in the runoff coefficient (\%) and soil loss ( $\mathrm{g} \cdot \mathrm{m}-2)$ partial least squares (PLS) models. SD: standard deviation; Fa: free aggregates; Fg: free gravel; Tc: total crust; Cha: charcoals; Res: residues; Wor: worm casts; Alg: algae; Mos: mosses; Ped: pedestals; Und: understory.

Author Contributions: Conceptualization, O.S., B.S. (Bounthan Souksavath), B.L., and O.R.; methodology, A.d.R., C.V., and O.R.; formal analysis, L.S., O.R., and L.B.; data curation, L.S., C.V., P.S., A.d.R., B.S. (Bounsamay Soulileuth), N.S., and O.R.; writing—original draft preparation, L.S.; writing—review and editing, L.B., O.R., A.P., C.V., and A.d.R.; visualization, L.S. and O.R.; supervision, L.B., O.R., and C.O.; funding acquisition, O.R. and A.P. All authors have read and agreed to the published version of the manuscript.

Funding: This research was funded by the French National Research Agency TecItEasy project, grant number ANR-13-AGRO-0007, and by a scholarship of French government and Ministry of Education, Youth and Sports of Cambodia (L.S.).

Acknowledgments: This study was supported by the Luang Prabang Teak Programme (LPTP), the French Institute for Sustainable Development (IRD) through the international joint laboratory LUSES (Dynamic of Land Use Changes and Soil Ecosystem Services), and the Faculty of Agriculture of Lao PDR and Lao students, namely VACHOIMA Sythong and TONGSENG Chong Moua. The authors sincerely thank the M-TROPICS Critical Zone Observatory (https://mtropics.obs-mip.fr/), which belongs to the French Research Infrastructure OZCAR (http://www.ozcar-ri.org/), and the Lao Department of Agricultural Land Management (DALaM) for their support, including granting the permission for field access.

Conflicts of Interest: The authors declare no conflict of interest. 


\section{References}

1. Gerstengarbe, F.W.; Werner, P.C. Precipitation Pattern. In Encyclopedia of Ecology; Jørgensen, S.E., Fath, B.D., Eds.; Elsevier Science: Amsterdam, The Netherlands, 2008; pp. 2916-2923. [CrossRef]

2. Descroix, L.; González Barrios, J.L.; Viramontes, D.; Poulenard, J.; Anaya, E.; Esteves, M.; Estrada, J. Gully and sheet erosion on subtropical mountain slopes: Their respective roles and the scale effect. Catena 2008, 72, 325-339. [CrossRef]

3. Valentin, C.; Agus, F.; Alamban, R.; Boosaner, A.; Bricquet, J.-P.; Chaplot, V.; De Guzman, T.; De Rouw, A.; Janeau, J.-L.; Orange, D. Runoff and sediment losses from 27 upland catchments in Southeast Asia: Impact of rapid land use changes and conservation practices. Agric. Ecosyst. Environ. 2008, 128, 225-238. [CrossRef]

4. Nandi, A.; Luffman, I. Erosion related changes to physicochemical properties of Ultisols distributed on calcareous sedimentary rocks. J. Sustain. Dev. 2012, 5, 52. [CrossRef]

5. Valentin, C.; Rajot, J.L. Erosion and Principles of Soil Conservation. In Soils as a Key Component of the Critical Zone 5: Degradation and Rehabilitation; Johns Hopkins University Press: Baltimore, MD, USA, 2018; Volume 5, pp. 39-82.

6. Sartori, M.; Philippidis, G.; Ferrari, E.; Borrelli, P.; Lugato, E.; Montanarella, L.; Panagos, P. A linkage between the biophysical and the economic: Assessing the global market impacts of soil erosion. Land Use Policy 2019, 86, 299-312. [CrossRef]

7. Panagos, P.; Borrelli, P.; Poesen, J.; Ballabio, C.; Lugato, E.; Meusburger, K.; Montanarella, L.; Alewell, C. The new assessment of soil loss by water erosion in Europe. Environ. Sci. Policy 2015, 54, 438-447. [CrossRef]

8. Pimentel, D.; Burgess, M. Soil erosion threatens food production. Agriculture 2013, 3, 443-463. [CrossRef]

9. Pimentel, D. Soil erosion: A food and environmental threat. Environ. Dev. Sustain. 2006, 8, 119-137. [CrossRef]

10. Owens, P.; Batalla, R.; Collins, A.; Gomez, B.; Hicks, D.; Horowitz, A.; Kondolf, G.; Marden, M.; Page, M.; Peacock, D. Fine-grained sediment in river systems: Environmental significance and management issues. River. Res. Appl. 2005, 21, 693-717. [CrossRef]

11. Yuan, S.; Tang, H.; Xiao, Y.; Xia, Y.; Melching, C.; Li, Z. Phosphorus Contamination of the Surface Sediment at a River Confluence. J. Hydrol. 2019, 573, 568-580. [CrossRef]

12. Chartin, C.; Evrard, O.; Onda, Y.; Patin, J.; Lefèvre, I.; Ottlé, C.; Ayrault, S.; Lepage, H.; Bonté, P. Tracking the early dispersion of contaminated sediment along rivers draining the Fukushima radioactive pollution plume. Anthropocene 2013, 1, 23-34. [CrossRef]

13. Turner, J.N.; Brewer, P.A.; Macklin, M.G. Fluvial-controlled metal and As mobilisation, dispersal and storage in the Rio Guadiamar, SW Spain and its implications for long-term contaminant fluxes to the Donana wetlands. Sci. Total. Environ. 2008, 394, 144-161. [CrossRef] [PubMed]

14. Domagalski, J.L.; Kuivila, K.M. Distributions of pesticides and organic contaminants between water and suspended sediment, San Francisco Bay, California. Estuaries 1993, 16, 416-426. [CrossRef]

15. Gateuille, D.; Evrard, O.; Lefevre, I.; Moreau-Guigon, E.; Alliot, F.; Chevreuil, M.; Mouchel, J.M. Mass balance and decontamination times of Polycyclic Aromatic Hydrocarbons in rural nested catchments of an early industrialized region (Seine River basin, France). Sci. Total. Environ. 2014, 470, 608-617. [CrossRef] [PubMed]

16. Ribolzi, O.; Cuny, J.; Sengsoulichanh, P.; Mousques, C.; Soulileuth, B.; Pierret, A.; Huon, S.; Sengtaheuanghoung, O. Land use and water quality along a Mekong tributary in northern Lao P.D.R. Environ. Manag. 2011, 47, 291-302. [CrossRef] [PubMed]

17. Boithias, L.; Choisy, M.; Souliyaseng, N.; Jourdren, M.; Quet, F.; Buisson, Y.; Thammahacksa, C.; Silvera, N.; Latsachack, K.; Sengtaheuanghoung, O.; et al. Hydrological Regime and Water Shortage as Drivers of the Seasonal Incidence of Diarrheal Diseases in a Tropical Montane Environment. PLoS. Negl. Trop. Dis. 2016, 10, e0005195. [CrossRef] [PubMed]

18. Kim, M.; Boithias, L.; Cho, K.H.; Sengtaheuanghoung, O.; Ribolzi, O. Modeling the Impact of Land Use Change on Basin-scale Transfer of Fecal Indicator Bacteria: SWAT Model Performance. J. Environ. Qual. 2018, 47, 1115-1122. [CrossRef]

19. Thothong, W.; Huon, S.; Janeau, J.-L.; Boonsaner, A.; de Rouw, A.; Planchon, O.; Bardoux, G.; Parkpian, P. Impact of land use change and rainfall on sediment and carbon accumulation in a water reservoir of North Thailand. Agric. Ecosyst. Environ. 2011, 140, 521-533. [CrossRef] 
20. Zarris, D.; Vlastara, M.; Panagoulia, D. Sediment Delivery Assessment for a Transboundary Mediterranean Catchment: The Example of Nestos River Catchment. Water Resour. Manag. 2011, 25, 3785. [CrossRef]

21. Efthimiou, N.; Lykoudi, E.; Panagoulia, D.; Karavitis, C. Assessment of soil susceptibility to erosion using the EPM and RUSLE Models: The case of Venetikos River Catchment. Global NEST J. 2016, 18, 164-179.

22. Sidle, R.C.; Ziegler, A.D.; Negishi, J.N.; Nik, A.R.; Siew, R.; Turkelboom, F. Erosion processes in steep terrain-Truths, myths, and uncertainties related to forest management in Southeast Asia. For. Ecol. Manag. 2006, 224, 199-225. [CrossRef]

23. Patin, J.; Mouche, E.; Ribolzi, O.; Chaplot, V.; Sengtahevanghoung, O.; Latsachak, K.O.; Soulileuth, B.; Valentin, C. Analysis of runoff production at the plot scale during a long-term survey of a small agricultural catchment in Lao PDR. J. Hydrol. 2012, 426, 79-92. [CrossRef]

24. Ziegler, A.D.; Giambelluca, T.W.; Tran, L.T.; Vana, T.T.; Nullet, M.A.; Fox, J.; Vien, T.D.; Pinthong, J.; Maxwell, J.F.; Evett, S. Hydrological consequences of landscape fragmentation in mountainous northern Vietnam: Evidence of accelerated overland flow generation. J. Hydrol. 2004, 287, 124-146. [CrossRef]

25. Ziegler, A.D.; Giambelluca, T.W.; Nullet, M.A.; Sutherland, R.A.; Tantasarin, C.; Vogler, J.B.; Negishi, J.N. Throughfall in an evergreen-dominated forest stand in northern Thailand: Comparison of mobile and stationary methods. Agric. For. Meteorol. 2009, 149, 373-384. [CrossRef]

26. Valentin, C. (Ed.) Soil Surface Crusting of Soil and Water Harvesting. In Soils as a Key Component of the Critical Zone 5: Degradation and Rehabilitation; John Wiley \& Sons: New York, NY, USA, 2018; Volume 5, pp. 21-38.

27. Goebes, P.; Seitz, S.; Kühn, P.; Li, Y.; Niklaus, P.A.; Oheimb, G.v.; Scholten, T. Throughfall kinetic energy in young subtropical forests: Investigation on tree species richness effects and spatial variability. Agric. For. Meteorol. 2015, 213, 148-159. [CrossRef]

28. Lacombe, G.; Ribolzi, O.; de Rouw, A.; Pierret, A.; Latsachak, K.; Silvera, N.; Pham Dinh, R.; Orange, D.; Janeau, J.L.; Soulileuth, B.; et al. Contradictory hydrological impacts of afforestation in the humid tropics evidenced by long-term field monitoring and simulation modelling. Hydrol. Earth Syst. Sci. 2016, 20, 2691-2704. [CrossRef]

29. Ribolzi, O.; Evrard, O.; Huon, S.; de Rouw, A.; Silvera, N.; Latsachack, K.O.; Soulileuth, B.; Lefevre, I.; Pierret, A.; Lacombe, G.; et al. From shifting cultivation to teak plantation: Effect on overland flow and sediment yield in a montane tropical catchment. Sci. Rep. 2017, 7, 3987. [CrossRef]

30. Lacombe, G.; Valentin, C.; Sounyafong, P.; de Rouw, A.; Soulileuth, B.; Silvera, N.; Pierret, A.; Sengtaheuanghoung, O.; Ribolzi, O. Linking crop structure, throughfall, soil surface conditions, runoff and soil detachment: 10 land uses analyzed in Northern Laos. Sci. Total. Environ. 2018, 616, 1330-1338. [CrossRef]

31. Patin, J.; Mouche, E.; Ribolzi, O.; Sengtahevanghoung, O.; Latsachak, K.O.; Soulileuth, B.; Chaplot, V.; Valentin, C. Effect of land use on interrill erosion in a montane catchment of Northern Laos: An analysis based on a pluri-annual runoff and soil loss database. J. Hydrol. 2018, 563, 480-494. [CrossRef]

32. Ribolzi, O.; Patin, J.; Bresson, L.M.; Latsachack, K.O.; Mouche, E.; Sengtaheuanghoung, O.; Silvera, N.; Thiébaux, J.P.; Valentin, C. Impact of slope gradient on soil surface features and infiltration on steep slopes in northern Laos. Geomorphology 2011, 127, 53-63. [CrossRef]

33. Chaplot, V.; Khampaseuth, X.; Valentin, C.; Bissonnais, Y.L. Interrill erosion in the sloping lands of northern Laos subjected to shifting cultivation. Earth Surf. Process. Landf. 2007, 32, 415-428. [CrossRef]

34. Vannoppen, W.; Vanmaercke, M.; De Baets, S.; Poesen, J. A review of the mechanical effects of plant roots on concentrated flow erosion rates. Earth Sci. Rev. 2015, 150, 666-678. [CrossRef]

35. Shinohara, Y.; Otani, S.; Kubota, T.; Otsuki, K.; Nanko, K. Effects of plant roots on the soil erosion rate under simulated rainfall with high kinetic energy. Hydrol. Sci. J. 2016, 61, 2435-2442. [CrossRef]

36. Roose, E. Land Husbandry: Components and Strategy; FAO: Rome, Italy, 1996.

37. Ehigiator, O.A.; Anyata, B.U. Effects of land clearing techniques and tillage systems on runoff and soil erosion in a tropical rain forest in Nigeria. J. Environ. Manag. 2011, 92, 2875-2880. [CrossRef] [PubMed]

38. Cerdà, A.; Rodrigo-Comino, J.; Giménez-Morera, A.; Novara, A.; Pulido, M.; Kapović-Solomun, M.; Keesstra, S.D. Policies can help to apply successful strategies to control soil and water losses. The case of chipped pruned branches (CPB) in Mediterranean citrus plantations. Land Use Policy 2018, 75, 734-745. [CrossRef]

39. Li, X.; Niu, J.; Xie, B. The effect of leaf litter cover on surface runoff and soil erosion in Northern China. PLOS ONE 2014, 9, e107789. [CrossRef] 
40. Durán Zuazo, V.H.; Martínez, J.R.F.; Pleguezuelo, C.R.R.; Martínez Raya, A.; Rodríguez, B.C. Soil-erosion and runoff prevention by plant covers in a mountainous area (se spain): Implications for sustainable agriculture. Environmentalist 2006, 26, 309-319. [CrossRef]

41. Poesen, J. Conditions for gully formation in the Belgian loam belt and some ways to control them. In Proceedings of the of Soil Erosion Protection Measures in Europe. Proc. EC Workshop, Freising, Germany, 24-26 May 1988; pp. 39-52.

42. Valentin, C.; Ruiz Figueroa, J. Effects of kinetic energy and water application rate on the development of crusts in a fine sandy loam soil using sprinkling irrigation and rainfall simulation. Micromorphol. Sols 1987, 401-408.

43. Van Dijk, A.; Bruijnzeel, L.; Eisma, E. A methodology to study rain splash and wash processes under natural rainfall. Hydrol. Process. 2003, 17, 153-167. [CrossRef]

44. Neyret, M.; Robain, H.; de Rouw, A.; Janeau, J.-L.; Durand, T.; Kaewthip, J.; Trisophon, K.; Valentin, C. Higher runoff and soil detachment in rubber tree plantations compared to annual cultivation is mitigated by ground cover in steep mountainous Thailand. Catena 2020, 189, 104472. [CrossRef]

45. Pachas, A.N.A.; Newby, J.C.; Siphommachan, P.; Sakanphet, S.; Dieters, M.J. Broom grass in Lao PDR: A market chain analysis in Luang Prabang Province. For. Trees Livelihoods 2020, 1-18. [CrossRef]

46. Olson, D.M.; Dinerstein, E.; Wikramanayake, E.D.; Burgess, N.D.; Powell, G.V.N.; Underwood, E.C.; D'amico, J.A.; Itoua, I.; Strand, H.E.; Morrison, J.C.; et al. Terrestrial Ecoregions of the World: A New Map of Life on Earth: A new global map of terrestrial ecoregions provides an innovative tool for conserving biodiversity. Bioscience 2001, 51, 933-938. [CrossRef]

47. Pachas, A.; Sakanphet, S.; Midgley, S.; Dieters, M. Teak (Tectona grandis) silviculture and research: Applications for smallholders in Lao PDR. Aust. For. 2019, 82, 94-105. [CrossRef]

48. Casenave, A.; Valentin, C. A runoff capability classification system based on surface features criteria in semi-arid areas of West Africa. J. Hydrol. 1992, 130, 231-249. [CrossRef]

49. Ribolzi, O.; Lacombe, G.; Pierret, A.; Robain, H.; Sounyafong, P.; de Rouw, A.; Soulileuth, B.; Mouche, E.; Huon, S.; Silvera, N. Interacting land use and soil surface dynamics control groundwater outflow in a montane catchment of the lower Mekong basin. Agric. Ecosyst. Environ. 2018, 268, 90-102. [CrossRef]

50. Janeau, J.L.; Bricquet, J.P.; Planchon, O.; Valentin, C. Soil crusting and infiltration on steep slopes in northern Thailand. Eur. J. Soil. Sci. 2003, 54, 543-554. [CrossRef]

51. Valentin, C.; Casenave, A. Infiltration into sealed soils as influenced by gravel cover. Soil Sci. Soc. Am. J. 1992, 56, 1667-1673. [CrossRef]

52. Lacombe, G.; Ribolzi, O.; de Rouw, A.; Pierret, A.; Latsachak, K.; Silvera, N.; Pham Dinh, R.; Orange, D.; Janeau, J.L.; Soulileuth, B.; et al. Afforestation by natural regeneration or by tree planting: Examples of opposite hydrological impacts evidenced by long-term field monitoring in the humid tropics. Hydrol. Earth Syst. Sci. 2015, 12, 12615-12648. [CrossRef]

53. Janeau, J.-L.; Gillard, L.-C.; Grellier, S.; Jouquet, P.; Le, T.P.Q.; Luu, T.N.M.; Ngo, Q.A.; Orange, D.; Pham, D.R.; Tran, D.T.; et al. Soil erosion, dissolved organic carbon and nutrient losses under different land use systems in a small catchment in northern Vietnam. Agric. Water Manag. 2014, 146, 314-323. [CrossRef]

54. Vigiak, O.; Ribolzi, O.; Pierret, A.; Sengtaheuanghoung, O.; Valentin, C. Trapping efficiencies of cultivated and natural riparian vegetation of northern Laos. J. Environ. Qual. 2008, 37, 889-897. [CrossRef]

55. Valentin, C.; Bresson, L.-M. Morphology, genesis and classification of surface crusts in loamy and sandy soils. Geoderma 1992, 55, 225-245. [CrossRef]

56. Quinn, G.; Keough, M. Experimental Design and Data Analysis for Biologists; Cambridge University Press: Cambridge, UK, 2002.

57. Abdi, H. Partial least squares regression and projection on latent structure regression (PLS Regression). Wiley Interdiscip. Rev. Comput. Stat. 2010, 2, 97-106. [CrossRef]

58. Zaldívar Santamaría, E.; Molina Dagá, D.; Palacios García, A.T. Statistical Modelization of the Descriptor "Minerality" Based on the Sensory Properties and Chemical Composition of Wine. Beverages 2019, 5, 66.

59. Wold, S. PLS for multivariate linear modeling. Chemom. Methods Mol. Des. 1995, 195-218.

60. Bu, C.-F.; Wu, S.-F.; Yang, K.-B. Effects of physical soil crusts on infiltration and splash erosion in three typical Chinese soils. Int. J. Sediment Res. 2014, 29, 491-501. [CrossRef]

61. Fox, D.; Bryan, R.; Fox, C. Changes in pore characteristics with depth for structural crusts. Geoderma 2004, 120, 109-120. [CrossRef] 
62. Neave, M.; Rayburg, S. A field investigation into the effects of progressive rainfall-induced soil seal and crust development on runoff and erosion rates: The impact of surface cover. Geomorphology 2007, 87, 378-390. [CrossRef]

63. Rey, F.; Ballais, J.-L.; Marre, A.; Rovéra, G. Rôle de la végétation dans la protection contre l'érosion hydrique de surface. C. R. Geosci. 2004, 336, 991-998. [CrossRef]

64. Angelsen, A.; Kaimowitz, D. Is agroforestry likely to reduce deforestation. In Agroforestry and Biodiversity Conservation in Tropical Landscapes; Schroth, G., Fonseca, G.A.d., Harvey, C.A., Gascon, C., Vasconcelos, H.L., Izac, A.-M.N., Eds.; Island Press: Washington, DC, USA, 2004; pp. 87-106.

65. Blanco, J.A.; Lo, Y.-H. Forest Ecosystems: More Than Just Trees; BoD-Books on Demand: Norderstedt, Germany, 2012.

66. Podwojewski, P.; Orange, D.; Jouquet, P.; Valentin, C.; Janeau, J.; Tran, D.T. Land-use impacts on surface runoff and soil detachment within agricultural sloping lands in Northern Vietnam. Catena 2008, 74, 109-118. [CrossRef]

67. Kosmas, C.; Danalatos, N.; Cammeraat, L.H.; Chabart, M.; Diamantopoulos, J.; Farand, R.; Gutierrez, L.; Jacob, A.; Marques, H.; Martinez-Fernandez, J. The effect of land use on runoff and soil erosion rates under Mediterranean conditions. Catena 1997, 29, 45-59. [CrossRef]

68. Nouwakpo, S.K.; Weltz, M.A.; Green, C.H.M.; Arslan, A. Combining 3D data and traditional soil erosion assessment techniques to study the effect of a vegetation cover gradient on hillslope runoff and soil erosion in a semi-arid catchment. Catena 2018, 170, 129-140. [CrossRef]

69. Calder, I.R.; Hall, R.L.; Prasanna, K. Hydrological impact of Eucalyptus plantation in India. J. Hydrol. 1993, 150, 635-648. [CrossRef]

70. Geißler, C.; Kühn, P.; Böhnke, M.; Bruelheide, H.; Shi, X.; Scholten, T. Splash erosion potential under tree canopies in subtropical SE China. Catena 2012, 91, 85-93. [CrossRef]

71. Le, H.T.; Rochelle-Newall, E.; Ribolzi, O.; Janeau, J.L.; Huon, S.; Latsachack, K.; Pommier, T. Land use strongly influences soil organic carbon and bacterial community export in runoff in tropical uplands-. Land. Degrad. Dev. 2020, 31, 118-132. [CrossRef]

72. Fernández-Moya, J.; Alvarado, A.; Forsythe, W.; Ramírez, L.; Algeet-Abarquero, N.; Marchamalo-Sacristán, M. Soil erosion under teak (Tectona grandis Lf) plantations: General patterns, assumptions and controversies. Catena 2014, 123, 236-242. [CrossRef]

73. Jadidoleslam, N.; Mantilla, R.; Krajewski, W.F.; Goska, R. Investigating the role of antecedent SMAP satellite soil moisture, radar rainfall and MODIS vegetation on runoff production in an agricultural region. J. Hydrol. 2019, 579, 124210. [CrossRef]

74. Phan Ha, H.A.; Huon, S.; Henry des Tureaux, T.; Orange, D.; Jouquet, P.; Valentin, C.; De Rouw, A.; Tran Duc, T. Impact of fodder cover on runoff and soil erosion at plot scale in a cultivated catchment of North Vietnam. Geoderma 2012, 177, 8-17. [CrossRef]

75. Santamaría Leandro, F. Evaluación de la Pérdida de Suelo en Plantaciones de Teca, Bajo la Aplicación de Sistemas de Conservación de Suelos en Nicoya, Guanacaste. 1992. Available online: http://www. sidalc.net/cgi-bin/wxis.exe/?IsisScript=rednia.xis\&method=post\&formato=2\&cantidad=1\&expresion=mfn= 005930 (accessed on 2 February 2019).

76. Cao, X.; Song, C.; Xiao, J.; Zhou, Y. The optimal width and mechanism of riparian buffers for storm water nutrient removal in the Chinese eutrophic Lake Chaohu watershed. Water 2018, 10, 1489. [CrossRef]

77. Koonkhunthod, N.; Sakurai, K.; Tanaka, S. Composition and diversity of woody regeneration in a 37-year-old teak (Tectona grandis L.) plantation in Northern Thailand. For. Ecol. Manag. 2007, 247, 246-254. [CrossRef]

78. Kumar, D.; Bijalwan, A.; Kalra, A.; Dobriyal, M.J. Effect of shade and organic manure on growth and yield of patchouli [Pogostemon cablin (blanco) benth.] under teak (Tectona grandis lf) based agroforestry system. Indian For. 2016, 142, 1121-1129.

79. Schroeder, P. Agroforestry systems: Integrated land use to store and conserve carbon. Clim. Res. 1993, 3, 53-60. [CrossRef]

80. Chitra-Tarak, R.; Ruiz, L.; Dattaraja, H.S.; Kumar, M.M.; Riotte, J.; Suresh, H.S.; McMahon, S.M.; Sukumar, R. The roots of the drought: Hydrology and water uptake strategies mediate forest-wide demographic response to precipitation. J. Ecol. 2018, 106, 1495-1507. [CrossRef]

81. Balmford, A.; Whitten, T. Who should pay for tropical conservation, and how could the costs be met? Oryx 2003, 37, 238-250. [CrossRef] 
82. Harvey, C.A.; Villalobos, J.A.G. Agroforestry systems conserve species-rich but modified assemblages of tropical birds and bats. Biodivers. Conserv. 2007, 16, 2257-2292. [CrossRef]

83. Wunderle, J.M., Jr. The role of animal seed dispersal in accelerating native forest regeneration on degraded tropical lands. For. Ecol. Manag. 1997, 99, 223-235. [CrossRef]

84. Imron, M.; Tantaryzard, M.; Satria, R.; Maulana, I.; Pudyatmoko, S. Understory Avian Community In A Teak Forest Of Cepu, Central Java. J. Trop. For. Sci. 2018, 30, 509-518. [CrossRef]

85. Perrin, R. Pest management in multiple cropping systems. Agro-Ecosystems 1976, 3, 93-118. [CrossRef]

86. Monaghan, R.; Smith, L.; Muirhead, R. Pathways of contaminant transfers to water from an artificially-drained soil under intensive grazing by dairy cows. Agric. Ecosyst. Environ. 2016, 220, 76-88. [CrossRef]

87. Annandale, G.W. Reservoir sedimentation. In Encyclopedia of Hydrological Sciences; Wiley: New York, NY, USA, 2006. [CrossRef]

88. Boithias, L.; Terrado, M.; Corominas, L.; Ziv, G.; Kumar, V.; Marques, M.; Schuhmacher, M.; Acuna, V. Analysis of the uncertainty in the monetary valuation of ecosystem services-A case study at the river basin scale. Sci. Total. Environ. 2016, 543, 683-690. [CrossRef]

89. Crowder, B.M. Economic costs of reservoir sedimentation: A regional approach to estimating cropland erosion damage. J. Soil Water Conserv. 1987, 42, 194-197.

90. McHenry, J.R. RESERVOIR SEDIMENTATION 1. J. Am. Water Resour. Assoc. 1974, 10, 329-337. [CrossRef]

91. Dang, T.D.; Cochrane, T.A.; Arias, M.E. Quantifying suspended sediment dynamics in mega deltas using remote sensing data: A case study of the Mekong floodplains. Int. J. Appl. Earth Obs. Geoinf. 2018, 68, 105-115. [CrossRef]

92. Arias, M.E.; Cochrane, T.A.; Kummu, M.; Lauri, H.; Holtgrieve, G.W.; Koponen, J.; Piman, T. Impacts of hydropower and climate change on drivers of ecological productivity of Southeast Asia's most important wetland. Ecol. Model. 2014, 272, 252-263. [CrossRef]

93. Bhat, S.A.; Dar, M.U.D.; Meena, R.S. Soil erosion and management strategies. In Sustainable Management of Soil and Environment; Springer: New York, NY, USA, 2019; pp. 73-122.

94. Ahmad, N.S.B.N.; Mustafa, F.B.; Gideon, D. A systematic review of soil erosion control practices on the agricultural land in Asia. Int. Soil Water Conserv. Res. 2020. [CrossRef]

(C) 2020 by the authors. Licensee MDPI, Basel, Switzerland. This article is an open access article distributed under the terms and conditions of the Creative Commons Attribution (CC BY) license (http://creativecommons.org/licenses/by/4.0/). 